\title{
イオン選択性液膜界面における電位発生機構 の分子レベルでの解釈
}

\author{
遠田 浩司* \\ Studies on the mechanism of the potential generation at the surface \\ of ion-selective liquid membranes at the molecular level (Accounts) \\ Koji ToHDA * \\ *Department of Chemistry, School of Science, The University of Tokyo, 7-3-1, Hongo, \\ Bunkyo-ku, Tokyo 113
}

(Received 1 September 1995, Accepted 9 March 1996)

\begin{abstract}
Ion-selective charge separation at the surface of ionophore-incorporated liquid membranes was studied by observing optical second harmonic generation (SHG) and by using lipophilic photoresponsive ionophores as a molecular probe. It was found that SHG signals from the ionophore-incorporated membranes in contact with aqueous primary cation chloride solutions generally increased with increasing cation concentration and then leveled off. This can be explained by the formation of oriented and therefore SHG active cation-ionophore complexes at the membrane surface. It was found that the membrane potential and SHG signal changed in parallel. This result suggests that the observed membrane potentials were primarily governed by SHG active oriented cation complexes at the membrane surface. To further clarify the influence of the surface charge density on the phase boundary potential, photoresponsive ionophores were used as a molecular probe because the ratio of the ionophore conformers with different complexation affinities is controlled quantitatively by light irradiation without any change in the membrane composition. The photoinduced changes in the potentiometric responses were analyzed as a function of the surface charge density by using a surface model based on a double-diffuse layer. As a result, it was found that the photoinduced changes in the potentiometric response behaviors, even when the deviations from a Nernstian response were observed, are in good agreement with the values calculated on the basis of the proposed model. This agreement leads to the important conclusion that the sub-Nernstian response slope is attributed to the low surface charge density due to lower ionophore concentrations.
\end{abstract}

Keywords : liquid membrane-type ion-selective electrodes (ISE); ion-selective charge separation; optical second harmonic generation (SHG); photoresponsive ionophore.

東京大学大学院理学系研究科化学専攻: 113 東京都文 京区本郷 7-3-1

\author{
1 緒言 \\ 選択性に優れた液膜型イオン電極（液膜 ISE）の開発

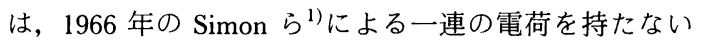


中性イオノフォア抗生物質を感応素子とする電極をきっ かけに始まった．特にバリノマイシンをジフェニルエー テルに溶解させた液膜をミリポアフィルターに含浸させ た液膜 ISE は，同じ強度の電位応答を起こす $\mathrm{K}^{+}$と $\mathrm{Na}^{+}$イオンの濃度比が 1:4000 という優れた $\mathrm{K}^{+}$イオ

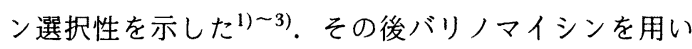
た $\mathrm{K}^{+}$イオン選択性電極の研究は盛んに行われ, ポリ 塩化ビニル（PVC）を ISE 液膜の支持材とすることや, テトラフェニルホウ酸誘導体等の脂溶性の高い陰イオン 性サイトの膜中への添加, 使用する有機溶媒の選択等に より, $\mathrm{K}^{+} / \mathrm{Na}^{+}$選択性は一万倍以上にまで改善され $た^{4)}$-6). 現在市販実用化されている $\mathrm{K}^{+}$イオン選択性 電極の大半は, バリノマイシンに基づくものである。一 方, 1967 年の Pedersen によるクラウンエーテルの最初 の報告をきっかけにして77), ホストーゲスト化学が Cram ら, Lehn らをはじめとする数多くのグループによって 急速に展開され ${ }^{899)}$, バリノマイシンと同じく金属イオ ンを電荷一双極子相互作用により捕そく, 抽出, 輸送す る環状, 非環状イオノフォアが開発され, これらが次々 と液膜 ISE の感応素子として用いられた ${ }^{10)}$. その結果, 金属イオンに対する数多くの優れたイオン選択性を有す る液膜 ISE が報告されてきている，そして現在の液膜 ISE 開発研究の流れは, 測定対象とする物質の範囲をこ れまでの金属イオンから無機陰イオン, 更に複雑な構造 を持つ有機イオンにまで拡張することとなりつつある.

一方, 電位応答機構の基礎論に関する研究としては, これまで主に膜相と水相バルク間の熱力学あるいは速度 論的な記述がなされてきた。例えば速度論的記述として は, 液/液界面の平衡電位をボルタンメトリーにおける 零電流電位として取り扱い, 膜電位やイオン選択性, イ オノフォアの効果を定量的に表現する理論式が報告され ている ${ }^{11)}$. しかし, ほとんどの場合, 液膜 ISE の電位 応答に関する一般的な説明はバルク間の目的イオンの熱 力学的平衡に基づき以下のように表現されている ${ }^{12)}$ : 膜 電位 $E_{\mathrm{M}}$ は, 膜内部で発生する電位差（いわゆる拡散 電位) $E_{\mathrm{D}}$ 及び液膜と試料溶液, 内部参照溶液界面で発 生する電位差（いわゆる界面電位） $E_{\mathrm{B}}{ }^{\prime}, E_{\mathrm{B}}{ }^{\prime \prime}$ の和,

$$
E_{\mathrm{M}}=E_{\mathrm{B}}{ }^{\prime}+E_{\mathrm{B}}{ }^{\prime \prime}+E_{\mathrm{D}}
$$

として表現される. 内部参照溶液濃度が一定であり, 又 膜中イオン濃度がどこでも変わらず一定であるという仮 定の下では, 膜電位は界面電位変化として表され,

$$
E_{\mathrm{M}}=E_{\text {const }}+\frac{R T}{z F} \ln \frac{k_{\mathrm{i}} a_{\mathrm{i}}}{[\mathrm{i}]}
$$

というネルンスト式が成立する.ここで $a_{\mathrm{i}}$ は, 試料溶
液中の目的イオン $\mathrm{i}$ の活量, $z$ は目的イオンの電荷数, [i] は界面膜側の目的イオンの活量, $k_{\mathrm{i}}$ は, 目的イオン の水相之膜相間の分配係数である. この界面電位は, 電 気透析, 放射線同位体 ${ }^{13) 14}$ などを用いる実験, 及び Morf ${ }^{15)}$, Pungor ${ }^{16)} ら の$ 詳細な議論によって, 膜界面で イオノフォアが陽イオンと選択的に高脂溶性の錯体を形 成し, 対陰イオンを試料溶液水相界面に残したまま, 正 電荷を帯びた錯体が膜内に浸透するいわゆる陽イオンパームセレクティビティーによって生じるものと考えら れている. しかし，膜相バルクと水相バルク間の目的 オンの熱力学的平衡論に基づき導出された式 (2)では, 液膜界面の陽イオンーパームセレクティビティーに関与 するイオノフォア錯体陽イオンの量, 分布と界面電位と の関係といった液膜界面の分子レベルでの機構は一切記 述されておらず，又実際の液膜 ISEでしばしば観測さ れるネルンスト電位応答からのずれ，検出下限を支配す る因子, コンディショニング時に液膜界面で生起してい る現象などについての説明は困難である.もし，この ISE 液膜界面における電位発生機構を分子レベルで記述 できれば，上述の問題に関しての明りょうな解答が得ら れ，更に優れた液膜 ISE 開発のための理論的な裏付け を与えるものと期待される.

このような液膜 ISE 研究の現状を踏まえ, 本論文で はレーザー光第二高調波発生 (SHG) や分子プローブ を用いる新しい手法によって, ISE 液膜界面における電 荷分離を分子レベルで解釈するために行った研究の成果 を述べる.

\section{2 レーザー光 SHG 法による ISE 液膜界面の} 電荷分離の直接観察 ${ }^{17) 18)}$

膜界面を観測する方法の一つに全反射赤外吸収分光法 (FTIR-ATR）がある.この手法によって， 0.3 1.8 $\mu \mathrm{m}$ の厚さの領域の膜界面情報（赤外スペクトル）を得るこ とができる. Pungor らは, FTIR-ATR 法を用いること により, イオノフォア含有液膜/試料溶液界面の観察を 行い, 膜を試料溶液に浸すことにより生成した膜界面の イオノフォアー陽イオン錯体由来の IR 吸収が, 膜を水 でリンスすることによって容易に消失することを見いだ している. 彼らは, この液膜界面での挙動が膜電位応答 と対応することから，膜電位応答を支配しているのは本 質的には膜バルクではなく, 界面であると結論した ${ }^{19)}$. 梅澤らは液膜界面の陽イオンーパームセレクティビテ イーを, 界面における錯体陽イオン及び対陰イオンの化 学量論比として定量的に検証することを目的に, 液膜 ISE 界面の FTIR-ATR 観察を行った. 陽イオンと錯体 
を形成すると IR 吸収バンドが変化する中性イオノフォ アと赤外活性な対陰イオンを用い, 液膜を試料溶液に浸 した後の膜界面の ATR スペクトルを測定すると，親水 性の対陰イオンを用いた場合, 約 $1 \mu \mathrm{m}$ の膜界面深さに おいてイオノフォア-陽イオン錯体の存在が確認された が, 対陰イオン由来の IR 吸収は観測されなかった。こ の結果は, $\mu \mathrm{m}$ オーダーの深さの液膜界面でイオノフォ アー陽イオン錯体の選択的輸送が達成されていることを 初めて分光的に検証するものである ${ }^{20)}$.

上述のように FTIR-ATR 法は, $\mu \mathrm{m}$ オーダーの厚み の膜界面における化学種の状態及び分布を知る有効な手 法であるが, 膜界面での電荷分離現象を分子レベルで総 合的に記述するためには, 更により薄い界面層の情報を 得る必要がある. この目的のため著者らは, 非線形光学 現象である SHG (second harmonic generation) 現象を 液膜界面観測に適用した ${ }^{17) 18}$.

SHG は, 周波数 $\omega$ の 2 光子を吸収し,それを周波 数 $2 \omega$ の 1 光子として放出する現象であり, これは中 心対称性を持たない場のみで発生するために，本質的に 界面現象に対して感度の高い手法である. 従って, 2 種 類の液体が接している場においては, 界面で配向した非 中心対象性を持つ分子のみが SHG 発生に寄与する.こ の液/液界面で発生する SHG 強度 $I(2 \omega)$ は, 界面に おける二次の非線形電気感受率 $\chi^{(2)}$ の二乗に比例す $ろ^{21)}$.

$$
\begin{aligned}
& I(2 \omega) \propto\left|\mathbf{e}(2 \omega) \cdot \chi^{(2)} \cdot \mathbf{e}(\omega) \mathbf{e}(\omega)\right|{ }^{2} I^{2}(\omega) \\
& \chi^{(2)}=N\langle T\rangle \alpha^{(2)}
\end{aligned}
$$

ここで, $I(\omega)$ は入射光の強度, $\mathbf{e}(\omega)$ と $\mathbf{e}(2 \omega)$ はそ れぞれ入射光と放射光の電気分極べクトルである. 又, $N$ は SHG 活性種の界面における濃度, $\alpha^{(2)}$ はその二次 の非線形分極率， $\langle T\rangle$ はその分子配向の平均である. 式 (3) 及び（4）より, SHG 強度の二乗根 $\sqrt{I(2 \omega)}$ は, $N,\langle T\rangle, \alpha^{(2)}$ に比例することが分かる. すなわ ち,

$$
\sqrt{I(2 \omega)} \propto N\langle T\rangle \alpha^{(2)}
$$

従って, 液膜/武料溶液界面における SHG 強度を測定 することによって, 界面における SHG 活性種の濃度, 分子配向及び分極率に関する情報が得られる.

Fig. 1 に, SHG 測定系の概略図を示す. 光源として ナノ秒パルス Nd : YAG レーザー (パルス幅 $10 \mathrm{~ns}: 10$ $\mathrm{Hz})$ の基本波 $(1064 \mathrm{~nm})$ を用いた。試料溶液と接して いる ISE 液膜に, $50 \mathrm{~mJ} / \mathrm{cm}^{2}$ の強度のパルスレーザー

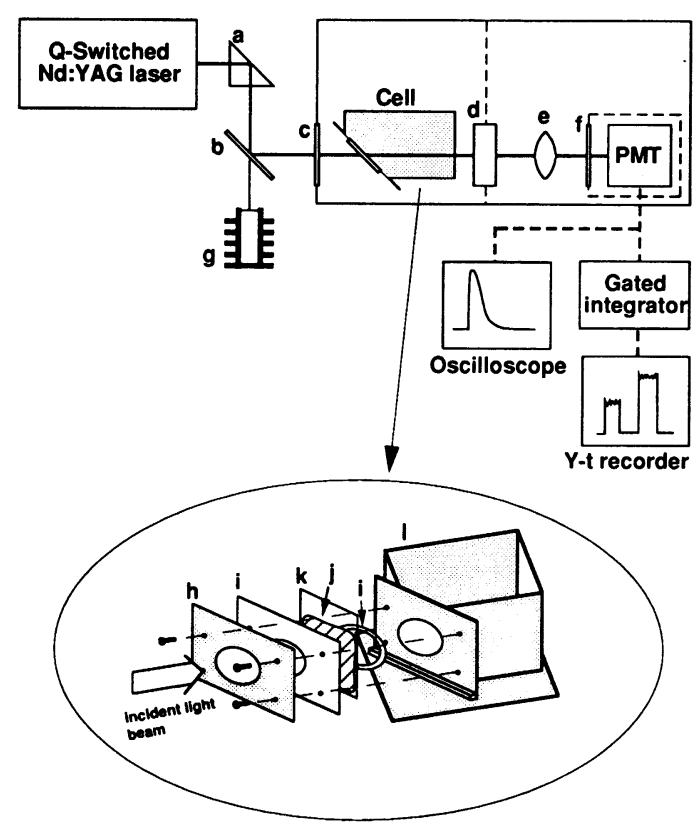

Fig. 1 Schematic diagram of the present SHG measuring system and detailed structure of the optical cell

a, $45^{\circ}$ right angle prism; b, glass plate reflector; c, infrared transparent filter $(>690 \mathrm{~nm})$; d, aqueous $\mathrm{CuSO}_{4}$ filter; $e$, spherical quartz lens; $f$, interference filter ( $530 \mathrm{~nm}, 10 \mathrm{~nm}$ of FWHM); g, beam damper; $h$, stainless cover; $i$, silicone rubber packing; $j$, solvent polymeric membrane; $k$, slide glass; 1 , sample cuvette

光を $45^{\circ}$ の角度で入射し, 発生した SHG 光 $(532 \mathrm{~nm})$ を光電子増倍管を用いて検出した。

$2 \cdot 1$ 液膜界面のイオノフォアー陽イオン錯形成に伴 う SHG 発生

Fig. 2 に, $\mathrm{Li}^{+}$イオノフォアであるジベンジル-14-ク ラウン -4 , 膜溶媒としてのセバシン酸ジオクチル （DOS）及び PVC からなるISE 液膜の $\mathrm{Li}^{+}$イオンに 対する SHG 応答を示す. 試料溶液中の $\mathrm{Li}^{+}$イオン （LiCl）濃度が増加するに従って SHG 強度も増加し, 高 $\mathrm{Li}^{+}$イオン濃度領域でほとんど一定の強度に達して いることが分かる．参照実験としてイオノフォアを含ま ない DOS と PVC のみからなる液膜からの SHG 測定 を同様の条件下で行ったが，ほとんど無視しうる強度の SHG しか観測されなかった。この結果は, 生成したイ オノフォア $-\mathrm{Li}^{+}$イオン錯体が界面を介して配向し SHG 


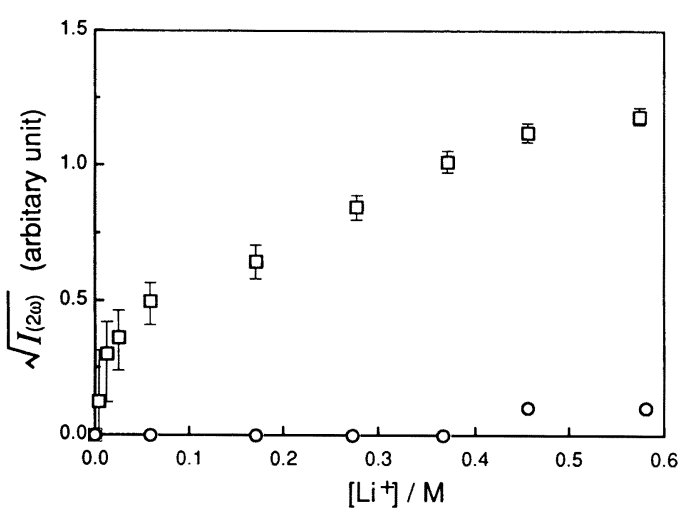

Fig. 2 Dependence of the square root of the SHG intensity $\left(\sqrt{I_{(2 \omega)}}\right)$ on $\mathrm{Li}^{+}$ion concentrations with a membrane based on dibenzyl-14-crown-4 ( $\square$, ionophore concentration $1.0 \times 10^{-2} \mathrm{M}$ ) or with a membrane without dibenzyl-14-crown-4 $(\bigcirc)$

Error bars show standard deviations.

活性種となっていること, 試料溶夜中の $\mathrm{Li}^{+}$イオン濃 度の増加に従って界面で配向した SHG 活性な錯体の数 も増加していることを示唆している.

この ISE 液膜の $\mathrm{Li}^{+}$イオンに対する SHG 応答が $\mathrm{Li}^{+}$イオンの高濃度領域で飽和するという現象に着目 し，膜界面における錯形成の過程をラングミュア等温吸 着式に基づいて解析した. Fig. 3 に, ジベンジル-14-ク ラウン -4 を 3, 10 及び $30 \mathrm{mM}$ 含む液膜の $\mathrm{SHG}$ 強度の 逆数と水溶液バルク中の $\mathrm{Li}^{+}$イオン濃度の逆数の関係 を示す (ラングミュアプロット). ラングミュア式によ れば, 吸着分子数 $N$ の逆数はバルク濃度 $C_{\mathrm{b}}$ の逆数に 正比例し, 切片は最大吸着量 $N_{\max }$ に対応する.すなわ ち,

$$
\frac{1}{N}=\left(\frac{1}{N_{\max } K}\right)\left(\frac{1}{C_{\mathrm{b}}}\right)+\frac{1}{N_{\max }}
$$

ここで, $K$ は結合定数 $\left(\mathrm{M}^{-1}\right)$ (膜界面における陽イオ ンーイオノフォア錯体の安定度定数）である. 式（6）に おいて, SHG 活性な陽イオン錯体の非線形分極率 $\alpha^{(2)}$ 及び分子配向 $\langle T\rangle$ が, 水溶液バルク中の $\mathrm{Li}^{+}$イオン濃 度に依存せず一定であると仮定すれば，SHG 強度の二 乗根 $\sqrt{I(2 \omega)}$ と SHG 活性な陽イオン錯体の量 $N$ は比 例する。実際, 膜中イオノフォア濃度が 10 及び 30 $\mathrm{mM}$ の場合，ラングミュアプロットに直線関係が見ら れることから，膜界面でラングミュア型の錯形成が起き ているものと考えられる. 又, イオノフォア濃度が 10

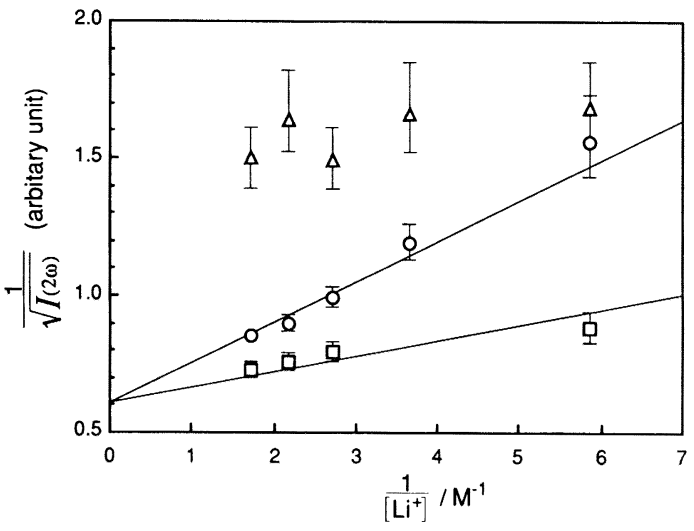

Fig. 3 Plots of the reciprocal of the square root of the SHG intensities $\left(1 / \sqrt{I_{(2 \omega)}}\right)$ versus the reciprocal of $\mathrm{Li}^{+}$ion concentrations in the adjacent aqueous solutions (the Langmuir isotherm) as obtained with a membrane based on dibenzyl-14-crown-4

The ionophore concentrations were $3.0 \times 10^{-3} \mathrm{M}$ $(\triangle), 1.0 \times 10^{-2} \mathrm{M}(\bigcirc)$ and $3.0 \times 10^{-2} \mathrm{M}(\square)$, respectively. The data points present averages for three sets of measurements. Error bars show standard deviations.

$\mathrm{mM}$ の場合, ラングミュアプロットの傾きから求めた 結合定数 $K$ は, $30 \mathrm{mM}$ の場合の約 3 倍であった (イオ ノフォア濃度 $10 \mathrm{mM}$ の場合 $4.2 \mathrm{M}^{-1}, 30 \mathrm{mM}$ の場合 $\left.11.5 \mathrm{M}^{-1}\right)$. 結合定数 $K$ は, 膜界面に存在する吸着サ イトの量（イオノフォアの界面濃度）を反映し，イオ， フォアの膜中濃度に比例するものと考えられるので, こ の結果はラングミュア式による解析の妥当性を示すもの である. 更に, 膜中イオノフォア濃度が $10 \mathrm{mM}$ の場合 と $30 \mathrm{mM}$ の場合, 最大吸着量を示すラングミュアプロ ットの切片がほぼ同じ値となった。この結果は, 水溶液 バルク中の $\mathrm{Li}^{+}$イオン濃度を十分に高くすると膜界面 で配向したイオノフォアー陽イオン錯体が高密度の分子 層を形成し，その表面濃度がどちらのイオノフォア濃度 の液膜の場合でもほぼ一定となっていることを示唆して いる. 一方, 膜中イオノフォア濃度が $3 \mathrm{mM}$ の液膜の ラングミュアプロットは, その切片の值が全く異なり, こう(勾) 配も非常に小さい。これは膜界面における吸 着サイトの量（イオノフォアの界面濃度）が少ないため に, 陽イオン錯体が膜界面で分子層を形成するほゼ生成 しなかったためと考えられる.後で述べるように，この 液膜の $\mathrm{Li}^{+}$イオンに対する電位応答は非常に小さかっ た.

この SHG 応答のラングミュア等温吸着式に基づいた 


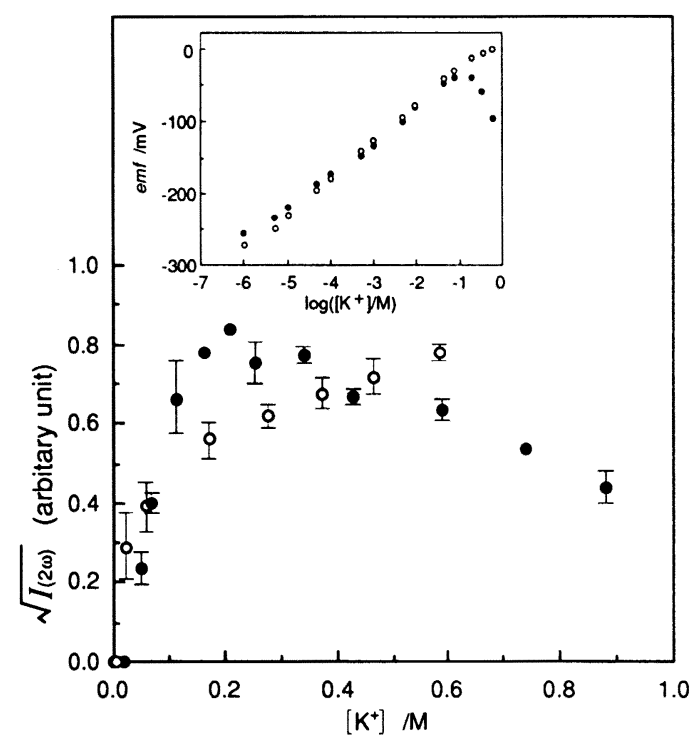

(a)

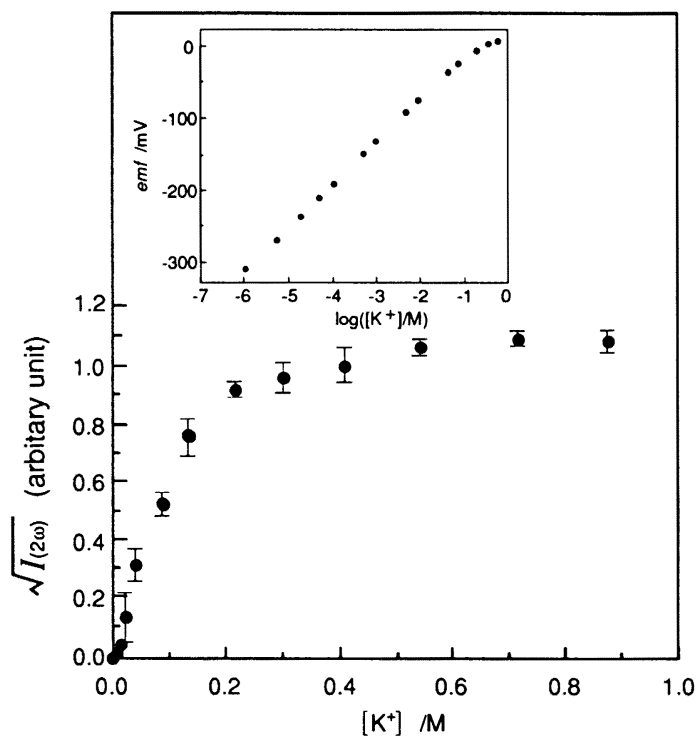

(b)

Fig. 4 Dependence of the square root of the SHG intensity $\left(\sqrt{I_{(2 \omega)}}\right)$ for a membrane based on bis(benzo-15-crown-5) without $\mathrm{KT} p \mathrm{CIPB}$ (a) and with $\mathrm{KT} p \mathrm{CIPB}$ (b) on $\mathrm{K}^{+}$ ion concentrations in the adjacent aqueous solution containing $\mathrm{KCl}(\mathrm{O})$ and $\mathrm{KSCN}$ (O), respectively.

Inset: The corresponding observed potentiometric responses to $\mathrm{KCl}(\mathrm{O})$ and $\mathrm{KSCN}$ (O), respectively. The concentrations of bis(benzo-15-crown-5) and KTpClPB were $3.0 \times 10^{-2} \mathrm{M}$ and $1.0 \times 10^{-2} \mathrm{M}$, respectively for both $\mathrm{SHG}$ and membrane potential measurements. The data points present averages for three sets of measurements. Error bars show standard deviations.

解析の結果は, 膜界面で SHG 活性な陽イオン錯体の凝 縮単分子層形成を示唆するものである. しかし，もし陽 イオン錯体が界面で生じている電場によって配向するな らば，単分子層よりも厚い錯体陽イオン層が界面で形成 されている可能性も考えられる.

\section{$2 \cdot 2$ SHG シグナルと膜電位の相関}

次に SHG 応答と膜電位応答の相関について検討を行 った. Fig. 4 に $\mathrm{K}^{+}$イオノフォアであるビスベンゾ-15クラウン -5 に基づく ISE 液膜の KSCN に対する SHG 応答と電位応答を示す．脂溶性の高い $\mathrm{SCN}^{-}$イオンを 対陰イオンとして用いると, 応答電位は KSCN 濃度が 増加するに従って増加するが, いわゆる陰イオン効果の ため, $\mathrm{KSCN}$ 濃度が $0.2 \mathrm{M}$ 付近で最大電位に達し, そ れ以降は減少する. 又, SHG 強度も同様に, KSCN 濃 度の増加とともに大きくなるが, 電位応答が減少し始め る濃度とほぼ同じ濃度のところで減少し始めていること が分かる. 一方, 膜中に脂溶性陰イオンであるテトラク
ロロフェニルボレート $(\mathrm{KT} p \mathrm{ClPB})$ を膜中イオン性サ イトとして添加すると, 膜中への $\mathrm{SCN}^{-}$イオンの侵入 が抑えられるため, 電位応答及び SHG 応答はいずれも 改善された.この電位応答と SHG 応答の類似性は, 膜 界面で生成した SHG 活性な錯体が膜電位を支配してい ることを示唆している.

そこで，膜電位に対する SHG 活性な錯体陽イオンの 寄与を評価するために, SHG 応答を, Gouy Chapman 理論に基づいた液/液界面の拡散二重層モデルを用いて 解析した ${ }^{15) 22)}$.このモデルに則って考えると, 界面膜 側の界面電荷密度 $\sigma^{\circ}$ 及び水溶液側の界面電荷密度 $\sigma^{\mathrm{a}}$ は, 界面電位の関数として以下のように表される.

$$
\begin{aligned}
& \sigma^{\mathrm{o}}=\sqrt{8 R T \overline{C_{\mathrm{b}}} \varepsilon_{0} \varepsilon} \sinh \left[\frac{F\left(\overline{\phi_{0}}-\overline{\phi_{\mathrm{b}}}\right)}{2 R T}\right] \\
& \sigma^{\mathrm{a}}=\sqrt{8 R T C_{\mathrm{b}} \varepsilon_{0} \varepsilon} \sinh \left[\frac{F\left(\phi_{0}-\phi_{\mathrm{b}}\right)}{2 R T}\right]
\end{aligned}
$$


ここで, $\overline{C_{\mathrm{b}}}$ 及び $C_{\mathrm{b}}$ は, それぞれイオンの膜中, 水溶 液中での濃度, $\varepsilon_{0}, \bar{\varepsilon}, \varepsilon$ は, 各々真空中の誘電率, 膜 及び水溶液中の比誘電率である. 又, $\overline{\phi_{\mathrm{b}}}, \phi_{\mathrm{b}}$ は, 膜バ ルク, 水溶夜バルクの電位, $\overline{\phi_{0}}, \phi_{0}$ は, 界面の膜側及 び水溶液側の外部へルムホルツ面における電位である.

ここで, 親水性の対陰イオンの水溶液側から膜側への抽 出が無視しうるほど少ないとすれば(すなわち陽イオンパームセレクティビティーが達成されているとき), 膜 中の錯体陽イオン濃度は, 電気的中性条件より, 液膜中 の脂溶性陰イオン濃度 $\left(\overline{C_{\mathrm{R}}}\right)$ と等しくなる.

$$
\overline{C_{\mathrm{b}}}=\overline{C_{R}}=\text { const. }
$$

電気的中性則により, 界面を介して分布している陽イオ ンと陰イオンの数が等しいと考えられるので $\left(\sigma^{\circ}=\right.$ $\left.-\sigma^{\mathbf{a}}\right)$, 式 (7) 及び (8) より膜バルクと水溶液バルク 間の電位差 $\left(\overline{\phi_{\mathrm{b}}}-\phi_{\mathrm{b}}\right)$ は, 界面の膜側及び水相側の外 部へルムホルツ面間の電位差が非常に小さいと仮定する と $\left(\overline{\phi_{0}}-\phi_{0} \approx 0\right)$, 以下のように表面電荷密度の関数と して表される.

$$
\begin{aligned}
\overline{\phi_{\mathrm{b}}}-\phi_{\mathrm{b}}= & \frac{2 R T}{F}\left(\operatorname{arcsinh}\left[\frac{\sigma^{\circ}}{\sqrt{8 R T \varepsilon_{\mathrm{o}} \bar{\varepsilon} \overline{C_{\mathrm{R}}}}}\right]\right. \\
& \left.+\operatorname{arcsinh}\left[\frac{\sigma^{\circ}}{\sqrt{8 R T \varepsilon_{\mathrm{o}} \varepsilon C_{\mathrm{b}}}}\right]\right)
\end{aligned}
$$

式（10）は，界面電荷密度から界面電位差が算出できる ことを示している，そこで, SHG 活性な陽イオン錯体 の量を界面電荷密度 $\sigma^{\circ}$ に対応させ, 式 (10) により算 出した界面電位差 $\left(\overline{\phi_{\mathrm{b}}}-\phi_{\mathrm{b}}\right)$ と実際の膜電位の相関を 調べることにより, SHG 活性種の膜電位に対する寄与 を定量的に評価することを試みた。しかし，SHG 強度 は SHG 活性種の界面濃度だけではなく，その分極率や 配向にも依存し，これらのパラメーターは一般には未知 なので, 直接 SHG 強度から SHG 活性な陽イオン錯体 濃度を求めることはできない，そこで次善の策として， 膜界面ではSHG 活性な錯体陽イオン層が単分子膜状で あると仮定して, 以下の手順で SHG 強度から SHG 活 性種の濃度を見積もった。まず SHG 強度の二乗根 $\sqrt{I(2 \omega)}$ は, SHG 活性な陽イオン錯体の濃度のみに比 例すると仮定した. 次に CPK 分子模型を用いて見積も った陽イオン錯体の分子占有面積を用いて，ラングミュ ア等温吸着式における最大吸着量 $N_{\text {max }}$ を求めた. $N_{\max }$ の値及び式 (5)，（6）を用いることにより，SHG 強度 から SHG 活性な陽イオン錯体の濃度を見積もった。

Fig. 5 にジベンジル-14-クラウン-4 を 3，10 及び 30 $\mathrm{mM}$ 含む液膜の, $\mathrm{Li}^{+}$イオン $(\mathrm{LiCl})$ に対する電位応 答と, 式(10) に基づいて SHG 応答から算出した電位

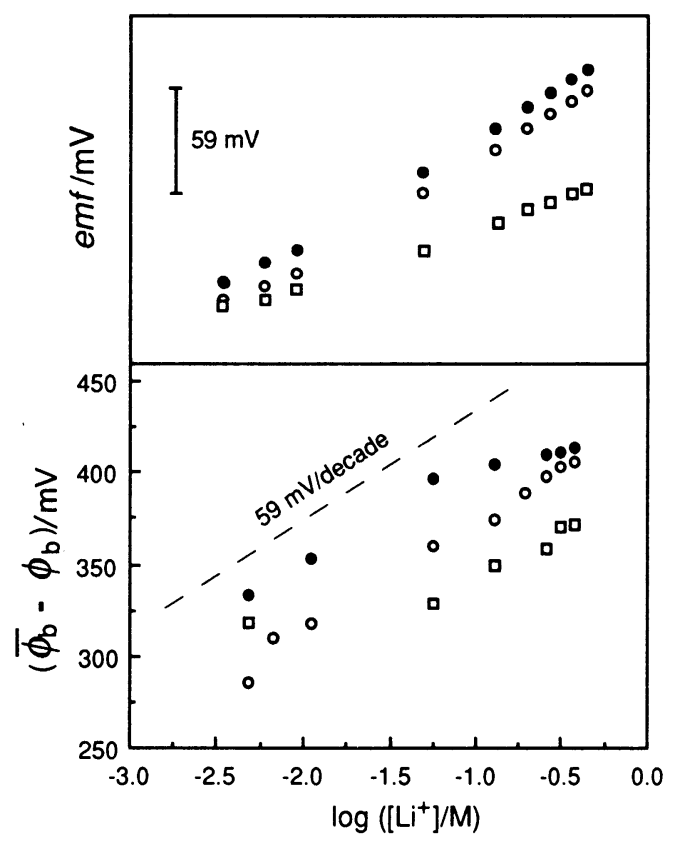

Fig. 5 Calculated potential differences, $\overline{\phi_{\mathrm{b}}}-\phi_{\mathrm{b}}$, across the membrane boundary of a membrane based on dibenzyl-14-crown-4 as a function of $\mathrm{Li}^{+}$ ion activity, as calculated from eq. 10

The upper data sets show the corresponding observed potentiometric responses. Ionophore concentration: $3.0 \times 10^{-3} \mathrm{M}(\square), 1.0 \times 10^{-2} \mathrm{M}(\bigcirc)$ and $3.0 \times 10^{-2} \mathrm{M}(\bigcirc)$, respectively. The following parameters were used: $\bar{\varepsilon}=4.0, \varepsilon=78.3, T=298 \mathrm{~K}$, and $\overline{C_{\mathrm{R}}}=1.0 \times 10^{-7} \mathrm{~mol} \cdot \mathrm{cm}^{-3}$.

差 $\left(\overline{\phi_{\mathrm{b}}}-\phi_{\mathrm{b}}\right)$ を示す．膜中イオノフォア濃度を $10 \mathrm{mM}$ とした膜では, SHG 応答から算出した界面電位差 $\left(\overline{\phi_{\mathrm{b}}}-\phi_{\mathrm{b}}\right)$ は $\mathrm{Li}^{+}$イオン濃度 $2.0 \times 10^{-3}$ から $3.0 \times 10^{-1}$ $\mathrm{M}$ の範囲で $58 \mathrm{mV} /$ decade の勾配であり，ネルンスト 応答 $\left(25^{\circ} \mathrm{C}\right.$ で $59.2 \mathrm{mV} /$ decade $)$ に非常に近い值を示し た。これは実際に測定した膜電位応答の結果ともほぼ一 致する.この結果は, 膜中イオノフォア濃度が $10 \mathrm{mM}$ という条件下では, 膜電位応答は SHG 活性な陽イオン 錯体の量によって支配されていることを示唆している. 一方，同じイオノフォアを用いた場合でも，その膜中濃 度を $30 \mathrm{mM}$ とした場合は, $\mathrm{Li}^{+}$イオンの高濃度領域で SHG 応答の飽和が起こるため, SHG 応答から算出した 電位応答の傾きも小さくなっている。これは, 実際に測 定した電位応答勾配が高 $\mathrm{Li}^{+}$イオン濃度領域でもネル ンスト応答に近い勾配を維持しているのとは対照的な結 果である. 更に, イオノフォア濃度を $3 \mathrm{mM}$ とした液 
膜では, SHG 応答に基づいて算出した電位応答勾配は わずか $25 \mathrm{mV} /$ decade であるが，この值は実際に測定し た膜電位応答勾配の值とよく一致する。これらのイオノ フォア濃度依存性の結果は, イオノフォア濃度の違いに よって膜界面を覆うSHG 活性な陽イオン錯体の量が異 なることを反映しているのであろう．特に，膜中イオノ フォア濃度が高い場合は, 比較的低い目的イオン濃度領 域で SHG 活性な錯体の飽和が起きており, そのため SHG 強度から見積もった電位応答勾配は実際に測定し た膜電位応答と比べて小さくなっているものと考えられ る. 従ってこの場合, 膜電位を支配しているのは, SHG 活性な陽イオン錯体だけでなく, 界面近傍の SHG 活性な陽イオン錯体層の内側に侵入した SHG 非活性な 陽イオン錯体も関与しているものと考えられる.

ここで, SHG 強度から式(10)に基づいて算出した電 位の結果のみから, 界面で SHG 活性な錯体の層が単分 子層であるとは言い切れないことを断わっておかなけれ ばならない，なぜなら上述の計算では表面電荷密度を CPK 分子模型の分子占有面積から求めたが, この表面 電荷密度の値を何倍か変化させても, 電位の絶対値は変 化するものの応答勾配はほとんど変化しないからであ る.

以上, SHG 活性な錯体の膜電位に対する寄与を考察 するために, SHG 活性陽イオン錯体の量が界面電荷密 度 $\sigma^{\circ}$ に等しいと仮定して拡散二重層モデルに基づいた 考察を行った.この拡散二重層モデルでは, 表面電荷密 度は拡散電気二重層内でボルツマン分布している点電荷 の総和として取り扱う。もし, 液膜界面において生成し たイオノフォアー陽イオン錯体が, 界面の電場により配 向し SHG 活性種になっているのであれば，膜界面にお ける電荷分布は拡散二重層モデルと矛盾しない。しか し, SHG 応答がラングミュア型の等温吸着式に従うこ とは, SHG 活性錯体陽イオンによる単分子層が膜界面 で形成されていることを示唆しており,この場合, 拡散 二重層モデルとは異なる電荷分布を考えなければならな い.すなわち，拡散二重層モデルでは取り扱われていな い陽イオン錯体の大きさや, 分子間の相互作用を考慮す る必要がある.このように, 液膜 ISE 界面の SHG 観 測結果は, 膜界面における SHG 活性なイオノフォア一 陽イオン錯体の量に関する情報を与えるのみならず, 拡 散二重層モデルの改良についても電荷の分布という観点 からの新たな情報を与えるものと考えられる.
3 光応答性イオノフォアを分子プローブとして 用いる電位応答機構解明のアプローチ

上述の ISE 液膜界面の SHG 観測における興味ある 結果の一つはイオノフォア濃度依存性である。すすな ち, 膜中イオノフォア濃度が低く, 目的イオンに対する 電位応答がサブ-ネルンスト勾配を示す液膜では, その SHG 応答も小さい.この場合, SHG 強度から上述の界 面電荷密度に基づくモデルで算出した応答勾配もサブネルンストであり,これは実測の電位応答勾配とほぼ等 しい (Fig. 5 参照).この SHG 測定の結果は, たとえ 非ネルンスト的応答が観測される場合であっても, 液膜 ISE の電位応答挙動を膜界面での目的陽イオンの取り込 みあるいは放出量, すなわち界面電荷密度で記述できる という一つの実験的な証拠を与えている.

それでは具体的に, 界面電荷密度に基づき液膜 ISE の電位応答挙動を正確に記述するために重要なことは何 かというと，ISE 液膜界面に取り込まれる目的陽イオン の量と膜電位応答の関係を定量的に知ることである。こ の目的のために, 上述の SHG 法は一つの有効な手段で あるが, 膜中イオノフォア濃度が高い場合, 膜電位の上 昇が観測される高目的陽イオン濃度領域で SHG 応答の 飽和が見られることから，膜電位応答を支配している錯 体陽イオンが常に SHG 活性であるとはいえない. 又, SHG 強度は, 界面における SHG 活性種の濃度だけで なく，その分子配向及び分極率にも依存し，これが膜電 位と界面錯体濃度の相関の厳密な解析を困難にしてい る.

近年，アゾベンゼンを結合させたベンゾ-15-クラウンー 5 に基づく PVC 液膜の膜電位が, 紫外光又は可視光照 射によって可逆的に変化することが，長らによって報告 された ${ }^{23) ~ 25) . ~}$ 目的陽イオンを含む水溶液に接している 光応答性イオノフォアに基づく液膜に可視，あるいは紫 外光を照射すると, 膜中イオノフォアの異性化に伴い, 膜電位変化が観測される. 彼らは, 電位変化の方向が膜 のよ゙ちら側に光を照射するかによって変化することか ら, 光誘起膜電位変化は膜の片側のみを光照射すること による膜の非対称性の生起に由来すると説明している.

一方, もしあらかじめ光応答性イオノフォアの光異性 化率と各イオノフォア異性体の目的イオンに対する錯体 生成定数を実験的に見積もっておけば，光照射により膜 界面でどれぐらいの数の目的陽イオンが取り込みあるい は放出され，それによって膜電位応答挙動がどう変わる のかを, 膜の状態を一切変えることなく定量的に知るこ とができるであろう、従って著者らは, 光応答性イオ, 
<smiles>CCOc1cc2c(cc1N=Nc1ccc3c(c1)OCCOCCOCCOCCO3)OCCOCCOCCOCCO2</smiles>

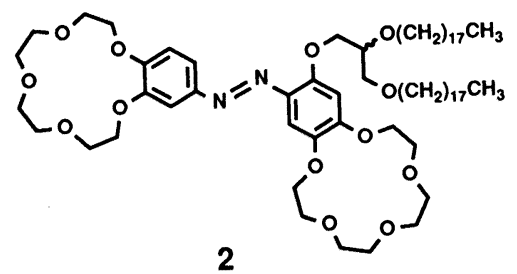<smiles>CCCOCCOCCOCCOc1ccc(N=Nc2ccc3c(c2)OCCOCCOCCOCCO3)cc1</smiles>

Fig. 6 Structures of the photoresponsive ionophores used in the present study

フォアが液膜 ISE の電位応答機構を界面電荷密度の観 点から調べる分子プローブの役割を果たすのではないか ということを思いついた，しかし，長らの報告した光応 答性イオノフォアは, 脂溶性が十分ではなく, 液膜から 水溶液へのイオノフォア溶出のため, 膜電位応答があま り安定でないことが報告されている.

そこで著者らは, 安定で再現性の良い光誘起膜電位応 答を得るためにアゾビス(ベンゾ-15-クラウン -5$)^{26)}$ の高 脂溶性誘導体 1, 2, 3（Fig. 6) を合成し, 膜界面での 目的イオンの取り込み量の変化が, 膜電位の絶対值, 応 答勾配によ゙ういう影響を及ぼすのかを定量的に調べる分 子プローブとして用いた．更に，界面の膜側，水溶液側 の二つの拡散電気二重層からなり, 界面の錯体形成平衡 を取り扱った界面モデルを用いて光誘起電位変化を解析 し, 液膜 ISE の電位応答が，ネルンスト応答から逸脱 する場合でも, 液膜界面の電荷密度の観点から予測でき るかどうかの検証を行った。

\section{$3 \cdot 1$ 膜電位分子プローブの光応答特性}

光応答性イオノフォアを膜界面における錯形成過程を 調べる膜電位分子プローブとして用いるために, 可視,
Table 1 The cis percentage of ionophores 1, 2 and 3 at the photostationary state in the PVC liquid membranes ${ }^{\dagger}$

\begin{tabular}{cc}
\hline ionophore & cis, \% \\
\hline $\mathbf{1}$ & 42 \\
$\mathbf{2}$ & 39 \\
$\mathbf{3}$ & 50 \\
\hline
\end{tabular}

$\dagger$ The ionophore concentration in the membrane was $1.0 \times 10^{-3} \mathrm{M}$ in all cases. The membrane thickness was $50 \mu \mathrm{m}$.

Table 2 Extraction of alkali metal picrates with ionophores 1, 2 and 3 under visible and UV light irradiation ${ }^{\dagger}$

\begin{tabular}{llllll}
\hline \multirow{2}{*}{ Ionophore } & \multicolumn{4}{c}{ Extracted picrate, \% } \\
\cline { 3 - 6 } & & $\mathrm{Na}^{+}$ & $\mathrm{K}^{+}$ & $\mathrm{Rb}^{+}$ & $\mathrm{Cs}^{+}$ \\
\hline \multirow{2}{*}{$\mathbf{2}$} & visible & 21.8 & 32.2 & 24.2 & 18.4 \\
& UV & 19.4 & 28.6 & 33.6 & 22.3 \\
& visible & 34.4 & 36.7 & 12.3 & 13.1 \\
& UV & 33.1 & 29.2 & 22.0 & 21.5 \\
& visible & 37.5 & 42.3 & 31.2 & 14.2 \\
& UV & 35.4 & 31.3 & 25.0 & 8.2 \\
\hline
\end{tabular}

$\dagger$ Organic phase (DBP): [ionophore] $=1.0 \times 10^{-3}$ $\mathrm{M}$; aqueous phase: [picric acid] $=5.0 \times 10^{-5} \mathrm{M}$, $[$ metal hydroxide $]=1.0 \times 10^{-3} \mathrm{M},[$ metal chloride $]=$ $5.0 \times 10^{-1} \mathrm{M}$.

紫外光照射時における膜中のシス体とトランス体イオノ フォアの濃度, 及びそのイオンに対する結合力（陽イオ ン錯体の安定度定数）を見積もった. 光源として 150 $\mathrm{W}$ の Xe ランプを使用し，ガラスフィルターを用いて 紫外光 $(<420 \mathrm{~nm})$ あるいは可視光 $(>490 \mathrm{~nm})$ を照 射した．液膜中のイオノフォアのシス体とトランス体の 濃度は, 紫外光あるいは可視光照射後, トランスーアゾ ベンゼンの $\pi-\pi^{*}$ 遷移に対応する吸収強度を測定する ことにより行った.これらのイオノフォアに基づく液膜 はいずれも 1 分以内で光定常状態に達した. Table 1 に，イオノフォア $1,2,3$ の紫外光照射によるシス体 とトランス体間の異性化率を示す．この異性化率は液膜 中のイオノフォア濃度を $0.01 \sim 10 \mathrm{mM}$ の範囲で変化さ せても，ほとんど一定であった.

光応答性イオノフォアの陽イオンに対する錯形成安定 度の評価は, 対応する金属ピクレートを用いた溶媒抽出 によって行った。なお，有機相としては膜溶媒であるフ タル酸ジブチル（DBP）を用いた. Table 2 に, 可視, 
紫外光照射下での $\mathrm{Na}^{+}, \mathrm{K}^{+}, \mathrm{Rb}^{+}, \mathrm{Cs}^{+}$イオンに対 する抽出率を示す.アゾビス(ベンゾ-15-クラウン -5) 誘 導体であるイオノフォア 1,2 を用いた場合は, 紫外光 照射により $\mathrm{Rb}^{+}$及び $\mathrm{Cs}^{+}$イオンの抽出率が増加して いることが分かる.これは, CPK 分子模型に基づいた 考察により，アゾビスクラウンのシス異性体が $\mathrm{Rb}^{+}$及 び $\mathrm{Cs}^{+}$イオンと安定なサンドイッチ型の $1: 1$ 錯体を 形成するためであると考えられる。これに対し， $\mathrm{K}^{+}$イ オンに対する抽出率は, 紫外光照射により減少する.

$\mathrm{K}^{+}$イオン存在下で，イオノフォア 2 及び 3 のトラン スーアゾベンゼンの $\pi-\pi^{*}$ 遷移に対応する吸収バンド が，20〜30 nm 短波長側にシフトすることを利用して連 続変化法による滴定を行った結果, トランスーイオノフ オア 1 及び 2 が, $\mathrm{K}^{+}$イオンと $2: 1$ (イオノフォア: 陽イオン）錯体を形成していることが明らかとなった. 紫外光照射下で $\mathrm{K}^{+}$イオンの抽出率が減少するのは, シス異性体 : $\mathrm{K}^{+}$イオン $(1: 1)$ 錯体よりもトランス異 性体: $\mathrm{K}^{+}$イオン $(2: 1)$ 錯体のほうが安定であるため と考えられる. 一方, 単環のアゾクラウン誘導体である イオノフォア 3 を用いた場合, いずれの金属イオンに 対しても紫外光照射下での抽出率が減少した．この溶媒 抽出実験の結果及び光定常状態における異性化率を用い て, 各々の陽イオンに対するシス異性体とトランス異性 体の錯形成定数の比 $\left(\beta_{\mathrm{IS}, \mathrm{cis}} / \beta_{\mathrm{IS}_{\mathrm{n}} \text {, } \text {,rans }}\right)$ を見積もること ができる. Table 3 にそれをまとめた.

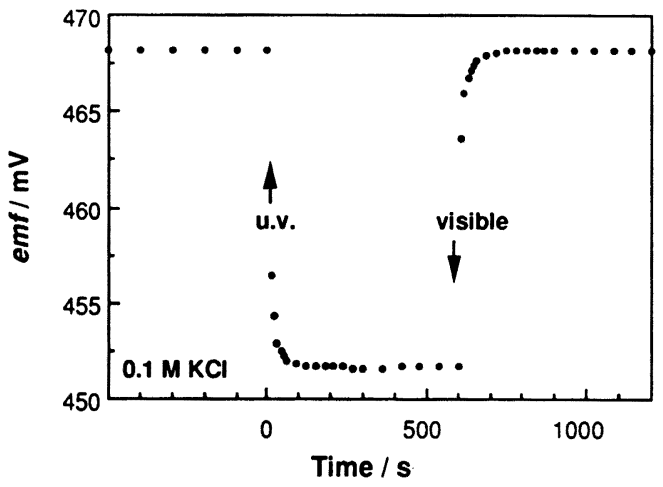

(a)
Table 3 The ratio of complexation stability constants between cis- and trans-conformers of ionophores 1, 2 and 3

\begin{tabular}{ccccc}
\hline \multirow{2}{*}{ Ionophore } & \multicolumn{4}{c}{$\beta_{\text {IS,cis }} / \beta_{\text {ISn,trans }}$} \\
\cline { 2 - 4 } & $\mathrm{Na}^{+}$ & $\mathrm{K}^{+}$ & $\mathrm{Rb}^{+}$ & $\mathrm{Cs}^{+}$ \\
\hline $\mathbf{1}$ & 0.74 & $3.11 \times 10^{-3 \dagger}$ & 1.93 & 1.51 \\
$\mathbf{2}$ & 0.90 & $5.25 \times 10^{-3 \dagger}$ & 2.42 & 2.64 \\
$\mathbf{3}$ & 0.89 & 0.48 & 0.60 & 0.15 \\
\hline
\end{tabular}

$\dagger$ The ratio was estimated under the assumption that the trans-ionophore forms a $2: 1$ (ionophore: cation) stoichiometric complex with $\mathrm{K}^{+}$ion.

\section{$3 \cdot 2$ 光で誘起される電位応答の変化とイオノフォア 濃度変化の相関}

光応答性イオノフォアに基づく液膜の膜電位測定のた めに，溶液/液膜界面を一つしか持たない， $\mathrm{BF}_{4}{ }^{-}$陰人 オンをドープしたポリピロール (PPy) 修飾白金電極に 液膜をコーティングしたものを ISE として用いた ${ }^{27)}$. この電極の電位安定性は良好で，例えばイオノフォア 2 に基づく液膜の $0.1 \mathrm{mM} \mathrm{RbCl}$ 溶液に対する応答電位の ドリフトは $0.3 \mathrm{mV} / \mathrm{h}$ 以下であり, 同じ組成の液膜を コーティングした場合の絶対電位のばらつきは \pm 3.0 $\mathrm{mV}$ 以下であった。この結果は, PPy 修飾白金電極が安 定な疑似内部参照電極となっていることを示している.

Fig. 7a に, 0.1 M KCl 溶液に接しているイオノフォ ア 1 に基づく液膜 ISE に, 紫外光及び可視光を照射し た場合の光誘起膜電位応答を示す. この液膜に紫外光を

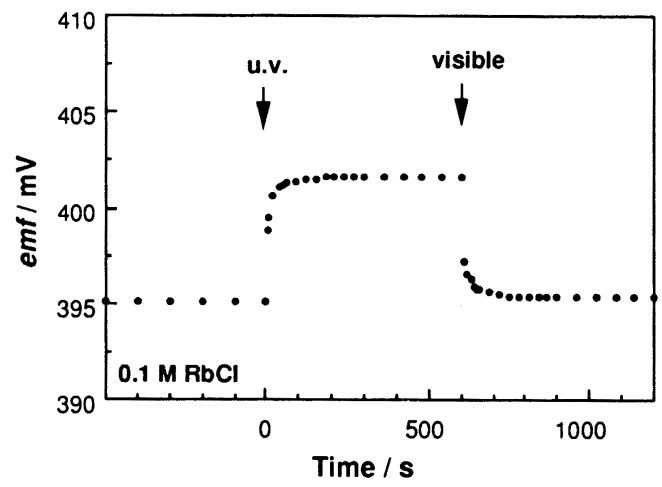

(b)

Fig. 7 Photoresponse of the membrane potential induced by UV and visible light irradiation for the membrane with ionophore 2 in contact with $0.1 \mathrm{M}$ of aqueous $\mathrm{KCl}$ (a) and $\mathrm{RbCl}$ (b)

The concentration of ionophore 2 was $1.0 \mathrm{mM}$. 
Table 4 Photoinduced potential changes, $\Delta e m f\left(e m f_{\left.\text {u.v. }-e m f_{\text {vis }}\right) \text {, for membranes }}{ }^{\text {a) }}\right.$ based on ionophores 1,2 and 3

\begin{tabular}{|c|c|c|c|c|c|c|}
\hline \multirow{3}{*}{ Ionophore } & & \multicolumn{4}{|c|}{$\Delta e m f$} & \\
\hline & \multicolumn{3}{|c|}{$\mathrm{KCl}(0.1 \mathrm{M})$} & \multicolumn{3}{|c|}{$\operatorname{RbCl}(0.1 \mathrm{M})$} \\
\hline & $\begin{array}{c}\text { Observed/ } \\
\mathrm{mV}\end{array}$ & $\begin{array}{c}\text { Calclated }^{\mathrm{b})} / \\
\mathrm{mV}\end{array}$ & $\begin{array}{c}\text { Calclated }^{\mathrm{c})} / \\
\mathrm{mV}\end{array}$ & $\begin{array}{c}\text { Observed/ } \\
\mathrm{mV}\end{array}$ & $\begin{array}{c}\text { Calclated }^{\mathrm{b})} / \\
\mathrm{mV}\end{array}$ & $\begin{array}{c}\text { Calclated }^{\mathrm{c})} / \\
\mathrm{mV}\end{array}$ \\
\hline 1 & -17.1 & -41.0 & -20.4 & 7.5 & 16.7 & 8.24 \\
\hline 2 & -12.6 & -26.6 & -13.2 & 11.0 & 22.8 & 11.3 \\
\hline 3 & -7.9 & -16.0 & -7.7 & -7.4 & -12.0 & -5.73 \\
\hline
\end{tabular}

a) The ionophore concentration in the membrane was $1.0 \times 10^{-3} \mathrm{M}$ in all cases. b) The potential changes were calculated from eq. 12. c) The potential changes were calculated from eq. 19.

照射すると膜電位は速やかに減少し，1 分以内でほぼ一 定の電位に達した．その後可視光を照射すると膜電位は 上昇し，最初の膜電位の值に戻った．光によって誘起さ れた膜電位変化の大きさ,すなわち $\Delta_{e m f}=e m f_{\mathrm{u} . \mathrm{v} .}-$

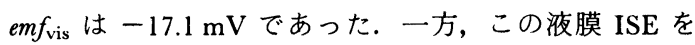
$0.1 \mathrm{M} \mathrm{RbCl}$ 溶液に浸した場合は, 紫外光を照射すると 膜電位は増加した。一定電位に達した後可視光を照射す ると電位は減少し，完全に元の電位に戻った（Fig， $7 \mathrm{~b})$. この場合, 光誘起による膜電位変化は, $+7.5 \mathrm{mV}$ であった．光照射による膜電位変化は可逆であり再現性 の良いものであった. Table 4 にイオノフォア 1, 2, 3 に基づく液膜の光誘起膜電位変化をまとめて示す．これ らの液膜の光照射による膜電位変化の方向が, 溶媒抽出 実験における陽イオン抽出挙動と対応しており, 又光応 答性イオノフォアでないビス(ベンゾ-15-クラウン-5) に 基づく液膜 ISE が, 光誘起膜電位変化を一切示さなか ったことから, 光応答性イオノフォアに基づく液膜にお ける光誘起膜電位変化は, イオノフォアのシス, トラン ス異性体変化及びそれに伴う陽イオンとの錯形成能変化 によって引き起こされる, 膜界面への陽イオンの取り込 み一放出によるものと考えられる.

次に, 光照射によって光応答性イオノフォアに基づく 液膜の目的イオンに対する電位応答勾配がごう変化する かについて調べた. Fig. 8a，bに，イオノフォア 2 を $1 \mathrm{mM}$ 及び $10 \mathrm{mM}$ 含む液膜の紫外及び可視光照射下に おける $\mathrm{RbCl}$ に対する電位応答を示す。この場合, 紫外 及び可視光照射下いずれも電位応答勾配はほとんど同じ であり $\mathrm{Rb}^{+}$イオン濃度が $10^{-4} \mathrm{M}$ 以上の濃度領域でほ ぼネルンスト応答を示した，又，紫外光照射下での膜電 位の絶対值が可視光照射の場合よりも大きいのは, イオ ノフォア 2 のシス異性体とトランス異性体の $\mathrm{Rb}^{+}$イオ ンに対する錯体形成能の違いを反映しているものと考え られる. 一方, 膜中イオノフォア濃度をサブ- $\mathrm{mM}$ まで
減少させると, 光照射下の電位応答勾配はいずれも減少 しサブーネルンスト応答を示したが, 紫外光照射下での 電位応答勾配が, 可視光照射の場合より大きいことが見 いだされた（Fig. 8c, d). 膜中イオノフォア濃度が低い 場合, 紫外光照射下では膜中のシス異性体濃度の増加に 伴って $\mathrm{Rb}^{+}$イオンに対する錯体形成能が大きくなり, 膜界面に取り込まれる $\mathrm{Rb}^{+}$イオンの量が増え, 電位応 答勾配が大きくなったものと考えられる.これらの結果 より, 膜中イオノフォア濃度の増加は膜電位の絶対値を 増加させるとともに, 電位応答勾配をネルンスト理論勾 配まで増加させることが分かった。

イオノフォア濃度の減少に伴って, 目的イオンに対す る電位応答勾配が減少する (サブーネルンスト応答) こ とは, 実験的によく知られた ISE 液膜の電位応答挙動 である ${ }^{28)}$.しかし、これまでネルンスト応答を示すた めの膜中イオノフォアの限界濃度に関する議論は実用面 だけに止まり，その理論的考察はほとんどされていな い. 一方, サブ-ネルンスト応答の理由の一つとして, 試料水溶液中の対陰イオンの膜中への共抽出による陽イ オンーパームセレクティビティーの阻害が指摘されてい る $^{12)}$.これによれば, 対陰イオンの膜中への抽出によ り膜内の拡散電位が変化し, これがサブーネルンスト応 答の由来であると説明されている. しかし，イオノフォ ア濃度の低い液膜においては, この拡散電位変化に基づ く説明は適切ではない.なぜなら, 低イオノフォア濃度 の液膜におけるサブ-ネルンスト応答は, 共抽出がほと んぞ起こらないと考えられる親水性の陰イオンを対陰 オンとして使用した場合でも一般に観測されるからであ る.これに対し, 光応答性イオノフォアを膜電位分子プ ローブとすることによって得られた上述の知見は, 膜中 イオノフォア濃度が低い結果, 膜界面への目的陽イオン の取り込み量が十分でなく,これがサブ-ネルンスト応 答勾配の原因であるという結論をもたらすであろう。こ 

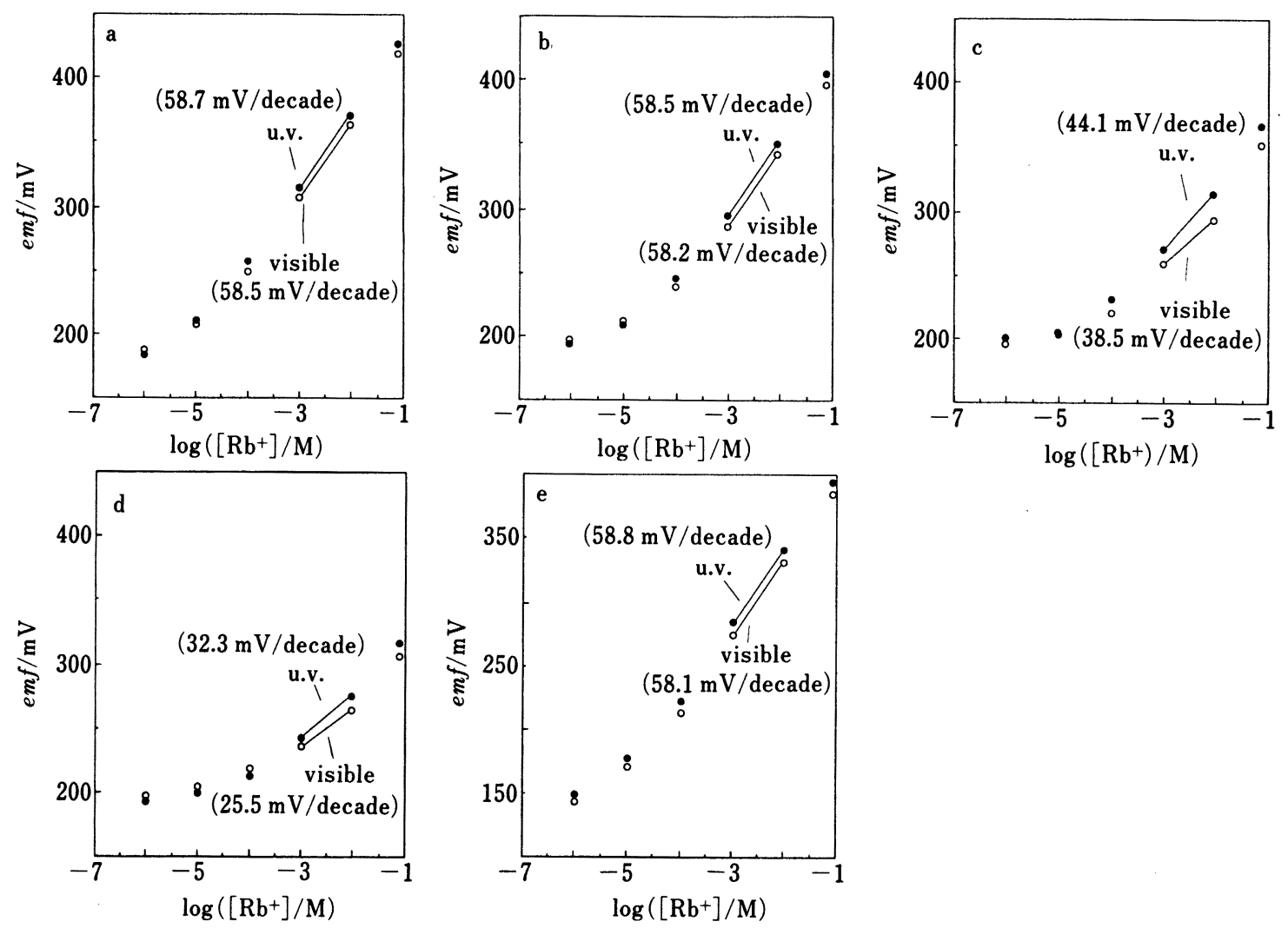

Fig. 8 Potentiometric responses toward $\mathrm{RbCl}$ of membranes 2 with various concentrations of ionophore 2 under UV and visible light irradiation The ionophore concentrations were (a) $10 \mathrm{mM}$, (b) $1 \mathrm{mM}$, (c) $0.1 \mathrm{mM}$, (d) $0.01 \mathrm{mM}$, respectively, and (e) $0.1 \mathrm{mM}$ with $10 \mathrm{~mol} \%$ (relative to the ionophore) of $\mathrm{KT} p \mathrm{CIPB}$.

の結論は, 低イオノフォア濃度の液膜において観測され た SHG 応答挙動, すなわち SHG 活性錯体濃度が低い ほよ゙, 観測される電位応答勾配が小さくなるという結果 によっても支持されている (2 章参照).

このサブーネルンスト忘答に関する考察に関連して, 液膜系ではなく LB 膜系ではあるが, 興味ある結果が長 らによって報告されている ${ }^{29)}$. 彼らは, 両親媒性のべ ンゾ(18-クラウン-6) 誘導体に基づく LB 膜を被覆した グラッシーカーボン電極が, 目的陽イオンに対して電位 応答することを見いだしているが，ここで重要なのは観 測された電位応答がすべてサブ-ネルンスト応答勾配を 示すことである．例えば, $\mathrm{K}^{+}$イオンに対する電位応答 勾配は，わずか $15 \mathrm{mV} /$ decade にしかすぎない. 更に彼 らは, 20 層のベンゾ(18-クラウン-6) 誘導体に基づく LB 膜で覆った電極も単分子 LB 膜で覆った電極も電位 応答勾配がほとんど変わらず，いずれもサブーネルンス
卜応答勾配を示すことを見いだしている.この結果か ら, 彼らは LB 膜被覆電極の電位応答は, LB 膜の最上 層に位置するイオノフォアと目的陽イオンの錯形成平衡 によって主に支配されていると結論している.このよう な LB 膜被覆電極のサブーネルンスト忍答挙動は, おそ らく低イオノフォア濃度の液膜と同様に, LB 膜の最上 層のイオノフォアのみが目的陽イオンと錯形成可能であ り，従って膜界面において目的陽イオンと錯形成できる イオノフォアの量が少なく, 結果として膜界面への目的 陽イオンの量が少なくなることに起因しているものと考 えられる. 膜界面における錯体陽イオンの深さ方向への 分布も電位応答勾配に影響を与えているのかもしれな w. 


\section{3 -3 液膜界面の電荷密度変化に基づく光誘起膜電位 変化の解析}

上述のようにして求めた光応答イオノフォアのシス, トランス異性体濃度及びイオンに対する安定度定数の比 $\left(\beta_{\mathrm{IS}, \mathrm{cis}} / \beta_{\mathrm{IS}_{\mathrm{n}} \text {, } \text {,rans }}\right)$ を用いて, ISE 液膜電位応答挙動の膜 中イオノフォア濃度依存性の定量的な解析を行った。こ の解析のため, 液膜/試料水溶液界面の拡散電気二重層 を取り扱う 2 種類の界面モデル（界面モデル I と II） を考えた。

最初のモデル（界面モデル I）では，液膜界面におけ る錯体陽イオン層（錯体陽イオンの単分子膜形成を仮定 して）と水相側界面の拡散二重層からなる界面を想定す る.これは外部から電場が加えられた場合の, 金属/電 解質界面に対する Gouy Chapman 理論と類似のモデル であり, 同様なモデルが長らによって, 光応答性イオ, フォアに基づく液膜の光誘起電位応答と界面電荷密度の 相関を記述するために用いられている ${ }^{25)}$. 界面モデル I において, 界面電荷密度 $\sigma^{\circ}$ と界面電位 $\phi_{\mathrm{s}}$ は式(11) で 表される。

$$
\sigma^{\circ}=\sqrt{8 R T C_{\mathrm{b}} \varepsilon_{0} \varepsilon} \sinh \left[\frac{F \phi_{\mathrm{s}}}{2 R T}\right]
$$

ここで界面電位が大きい場合 $\left(\phi_{\mathrm{s}} \gg R T\right)$, 界面電荷密度 の光誘起変化 $\Delta \sigma$ は, 界面電位変化と式 (12) で関連付 けられる。

$$
\Delta \phi_{\mathrm{s}}=\frac{2 R T}{F} \ln (\Delta \sigma)
$$

まず，このモデル I を用いて光誘起電位応答の解析を 行った．例えば，0.1 M の RbCl 溶液に接している，イ オノフォア 1 を $1.0 \mathrm{mM}$ 含む液膜に紫外光を照射する と, トランス異性体は $1.0 \mathrm{mM}$ から $0.58 \mathrm{mM}$ に減少 し, シス異性体は $0 \mathrm{mM}$ から $0.42 \mathrm{mM}$ まで増加する.

又, 溶媒抽出より見積もったイオノフォア異性体間の $\mathrm{Rb}^{+}$イオンに対する安定度定数の比は 1.93 である.こ れは，紫外光照射により $\mathrm{Rb}^{+}$イオン錯体の量が $39 \%$ 増加することに対応している，界面電荷密度が $39 \%$ 増 加した場合の膜電位変化は, 式 (12) を用いることによ り $+16.7 \mathrm{mV}$ と計算された。これは，実際に観測され た光誘起膜電位変化 $(+7.5 \mathrm{mV})$ と比べて 2 倍以上大 きな値である．Table 4 に式(12) を用いて計算した膜 電位変化の值をまとめた. いずれの場合にも, 計算で求 めた電位変化の絶対値は, 実測值よりも大きかった。こ のモデルに基づいて計算した膜電位変化と観測された光 誘起膜電位変化の違いは，モデル I における膜界面で

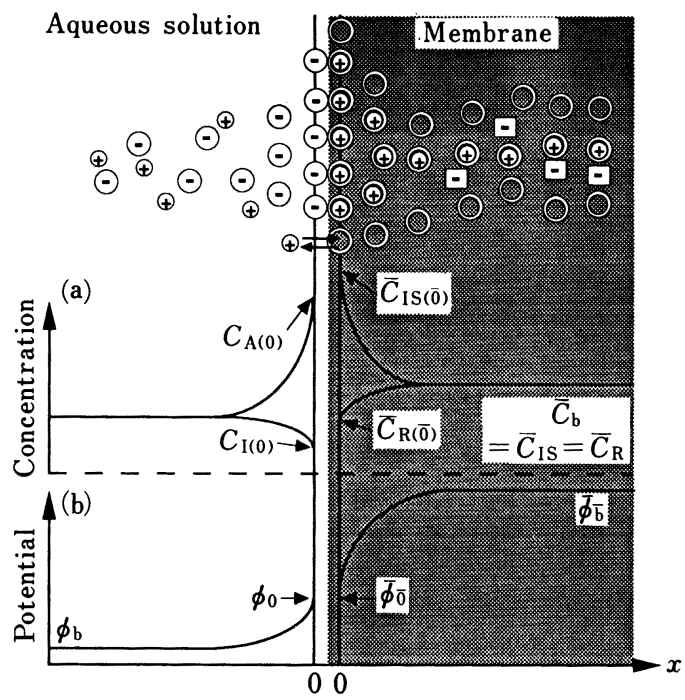

Fig. 9 Schematic representation of (a) the concentration and (b) the electric potential profiles at the membrane/sample solution interface

$x=0$ and $\overline{0}$ are positions of ions in planes of closest approach (outer Helmholtz planes) at the aqueous and the membrane side, respectively.

の錯体陽イオン単分子膜形成という仮定に由来している のであろう. 液/液界面を取り扱う電気化学の最近の展 開によれば，一般に界面の水相側及び有機溶媒相側の両 方に拡散電気二重層が形成されることが示されてい る ${ }^{30)}$. 従って, 界面モデル I は, 界面で生成した錯体 陽イオンが，その高い界面活性能のため界面に強く吸着 するか，あるいはイオノフォア包埋 LB 膜のようにイオ ノフォアが膜界面に固定化されている場合のみ適用が可 能であるものと考えられる.

そこで, 水相側の外部へルムホルツ面にある陽イオン と膜側の外部へルムホルツ面にあるイオノフォア間で錯 形成平衡が達成されており, すべてのイオン種が液膜/ 試料水溶液界面でボルツマン分布するモデルを考えた (界面モデル II, Fig. 9)。このモデルでは, 膜側の外部 ヘルムホルツ面における陽イオン錯体濃度 $\overline{C_{\mathrm{IS}}(\overline{0})}$ 及び 膜中脂溶性陰イオン濃度 $\bar{C}_{\mathrm{R}(0)}$ と界面電荷密度 $\sigma^{\circ}$ の関 係は式(13) で表される.

$$
\bar{C}_{\mathrm{IS}(\overline{0})}+\bar{C}_{\mathrm{R}(\overline{0})}=2 \bar{C}_{\mathrm{R}}+\frac{\left(\sigma^{\circ}\right)^{2}}{2 R T \varepsilon_{0} \bar{\varepsilon}}
$$

ここで, 膜中脂溶性陰イオンが水相側へ溶け出さず, 又, 水相側の対陰イオンも膜中に侵入しない場合は, 式 
（13）は式(14）に書き直すことができる.

$$
\sigma^{\circ}=\sqrt{2 R T \varepsilon_{0} \bar{\varepsilon}}\left(\sqrt{\bar{C}_{\mathrm{IS}(\overline{0})}}-\frac{\overline{C_{\mathrm{R}}}}{\sqrt{\overline{C_{\mathrm{IS}(\overline{0})}}}}\right)
$$

ここで, 全イオノフォア濃度 $\bar{C}_{\mathrm{S}, \text { tot }}$ が膜中脂溶性陰イオ ン濃度 $\bar{C}_{\mathrm{R}}$ より十分高く, 膜中の錯形成していないイオ ンフリーなイオノフォア濃度 $\left(\bar{C}_{\mathrm{S}, \text { tot }}-\bar{C}_{\mathrm{R}}\right)$ が膜中どこ でも一定である場合，外部へルムホルツ面における陽イ オン錯体濃度 $\bar{C}_{\mathrm{IS}(\overline{0})}$ は,

$$
\bar{C}_{\mathrm{IS}(\overline{0})}=\beta_{\mathrm{IS}} \bar{C}_{\mathrm{I}(\overline{0})}\left(\bar{C}_{\mathrm{S}, \mathrm{tot}}-\bar{C}_{\mathrm{R}}\right)
$$

と表される。ここで， $\beta_{\mathrm{IS}}$ はイオノフォア錯体 IS の安 定度定数, $\bar{C}_{\mathrm{I}(\overline{0})}$ は目的陽イオン $\mathrm{I}$ の膜側の外部ヘルム ホルツ面における濃度である。試料水溶液が目的イオン 塩しか含まない場合，この $\bar{C}_{\mathrm{I}(\overline{0})}$ は水溶液バルクの目的 イオン濃度 $C_{\mathrm{b}}$ を用いて以下のように表される.

$$
\begin{aligned}
& \bar{C}_{\mathrm{I}(\overline{0})}=k_{\mathrm{I}} C_{\mathrm{I}(0)}=\frac{k_{1}\left(C_{\mathrm{b}} \sqrt{\varepsilon \beta_{\mathrm{IS}} k_{1}\left(\bar{C}_{\mathrm{S}, \mathrm{tot}}-\bar{C}_{\mathrm{R}}\right)}+\bar{C}_{\mathrm{R}} \sqrt{\bar{\varepsilon}}\right.}{\sqrt{\varepsilon \beta_{\mathrm{IS}} k_{1}\left(\bar{C}_{\mathrm{S}, \mathrm{tot}}-\bar{C}_{\mathrm{R}}\right)+\sqrt{\varepsilon}}} \\
& k_{1}=\exp \left(\left\{\mu_{1}{ }^{0}(\mathrm{aq})-\mu_{1}{ }^{0}(\mathrm{org})\right\} / R T\right)
\end{aligned}
$$

ここで, $\bar{C}_{\mathrm{I}(\overline{0})}$ は, 水相側の外部へルムホルツ面におけ る目的イオン濃度, $\mu_{1}{ }^{0}(\mathrm{aq}), \mu_{1}{ }^{0}(\mathrm{org})$ は, 目的イオン の水相及び膜相における標準化学ポテンシャルである.

式 (14)，（15），(16）及び界面電荷密度と界面電位の関 係を記述する式(10) を用いて, 膜界面電位の水溶液バ ルクの目的イオン濃度依存性を算出することができる.

Fig. 10 に膜中イオノフォア濃度を変化させた場合の膜 界面電位の計算結果を示す.いずれのイオノフォア濃度 の場合も，ネルンスト理論式と一致した界面電位の目的 イオン濃度依存性が見られる。これは界面モデル II で は，すべてのイオン種がボルツマン分布則に従うと仮定 し, 従って拡散電気二重層中のイオン種は化学ポテンシ ヤルがいたるところで一様であると取り扱うため, 結果 として膜相バルクと水相バルク間のイオンの熱力学的平 衡で記述されるネルンスト式と一致するのである. 又, 膜中イオノフォア濃度が増加すると, 膜界面での目的 オン取り込み量の増大，すなわち界面電荷密度の増大を 反映して界面電位が増加していることが分かる.

次に，このモデルに基づいて光誘起膜電位変化の解析 を行った．光応答性イオノフォアを含む液膜に可視光を 照射した場合，膜中イオノフォアはすべてトランス異性 体であり，このトランス異性体が目的イオンと $n: 1$ （イオノフォア：陽イオン）の化学量論の錯体を形成す るとき，界面電位 $E_{\mathrm{vis}}$ は，

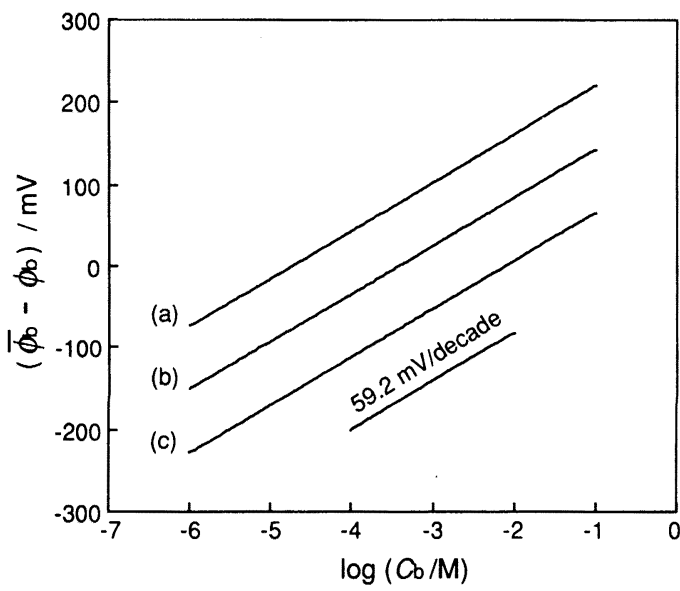

Fig. 10 Galculated potential differences, $\overline{\phi_{\mathrm{b}}}-\phi_{\mathrm{b}}$, as a function of the primary cation concentration, $C_{\mathrm{b}}$, with (a) $10 \mathrm{mM}$, (b) $1 \mathrm{mM}$ and (c) $0.1 \mathrm{mM}$ of the total ionophore concentration, respectively.

The curves were obtained by using eqs 10, 14, 15 and 16. The following parameters were used: $\beta_{\mathrm{IS}}=1.0 \times 10^{10} \mathrm{M}^{-1}, \quad k_{1}=1.3 \times 10^{-8}, \quad \varepsilon=78.3$, $\varepsilon=4.0, \overline{C_{\mathrm{R}}}=0.05 \mathrm{mM}$.

$$
\begin{aligned}
E_{\mathrm{vis}} & \approx \frac{R T}{F} \operatorname{arcsinh}\left[\frac{\bar{C}_{\mathrm{IS}_{\mathrm{n}}(\overline{0}) \text {,trans }}}{2 \bar{C}_{\mathrm{R}}}\right] \\
& \approx \frac{R T}{F} \ln \left[\frac{k_{\mathrm{l}} \beta_{\mathrm{IS} \mathrm{n}_{\mathrm{n}} \text {,rans }}\left(\bar{C}_{\mathrm{S}, \text { tot }}-\bar{C}_{\mathrm{R}}\right)^{n} C_{\mathrm{b}}}{\bar{C}_{\mathrm{R}}}\right]
\end{aligned}
$$

で表される，一方，液膜に紫外光を照射した場合，膜中 では，イオノフォアのシス異性体とトランス異性体が混 在しており, シス異性体が目的イオンと $1: 1$ 錯体を形 成するとき, その界面電位 $E_{\text {u.v. }}$. は以下のように表され る.

$$
\begin{aligned}
& E_{\text {u.v. }} \approx \frac{R T}{F} \operatorname{arcsinh}\left[\frac{\bar{C}_{\mathrm{IS}_{\mathrm{n}}(\overline{0}), \text { trans }}+\bar{C}_{\mathrm{IS}(\overline{0}), \mathrm{cis}}}{2 \bar{C}_{\mathrm{R}}}\right] \\
& \approx \frac{R T}{F} \ln \left[\frac{k_{1}\left(\beta_{\mathrm{IS}_{\mathrm{n}}, \text { trans }}\left(y \bar{C}_{\mathrm{S}, \text { trans, tot }}^{\mathrm{u} . \mathrm{v}}\right)^{n}+\beta_{\mathrm{IS} \text {, cis }} y \bar{C}_{\mathrm{S} \text {, cis, tot }}^{\mathrm{u}, \mathrm{v},}\right) C_{\mathrm{b}}}{\bar{C}_{\mathrm{R}}}\right] \\
& \text { ここで, } y=\frac{\bar{C}_{\mathrm{S}, \text { tot }}-\bar{C}_{\mathrm{R}}}{\bar{C}_{\mathrm{R}}}
\end{aligned}
$$

$\beta_{\mathrm{IS}_{\mathrm{n}}, \mathrm{trans}}, \beta_{\mathrm{IS} \text {, is }}$ は, イオノフォアのトランス異性体及 びシス異性体の目的イオンに対する錯形成安定度定数, $\bar{C}_{\mathrm{S} \text {,trans,tot }}^{\mathrm{u}, \mathrm{v}}, \bar{C}_{\mathrm{S} \text {, cis, tot }}^{\mathrm{u} . \mathrm{v}}$ は紫外光照射下でのトランス異性体 及びシス異性体の膜中濃度である. 式(17) と（18）から 光誘起膜電位変化 $\left(e m f_{\text {u.v. }}-e m f_{\text {vis }}\right)$ は次式のように表さ れる. 


$$
\begin{aligned}
& e m f_{\text {u.v. }}-e m f_{\text {vis }} \approx E_{\text {u.v. }}-E_{\text {vis }} \\
& \approx \frac{R T}{F} \ln \left[\frac{y^{n-1}\left(\bar{C}_{\mathrm{S}, \text { trans,tot }}^{\mathrm{u},{ }^{n}}\right)^{n}+\frac{\beta_{\mathrm{IS} \text { cis }}}{\beta_{\mathrm{IS}_{\mathrm{n}}, \mathrm{trans}}} C_{\mathrm{S}, \mathrm{vis}, \text { tot }}^{\mathrm{u} \mathrm{v}}}{y^{n-1}\left(\bar{C}_{\mathrm{S}, \mathrm{tot}}\right)^{n}}\right]
\end{aligned}
$$

すなわち，光応答性イオノフォアの目的イオンに対する シス,トランス異性体の錯形成安定度定数の比 ( $\beta_{\mathrm{IS} \text { cis }}$ ) $\left.\beta_{\mathrm{IS}_{\mathrm{n}}, \text { trans }}\right)$, 及び紫外光照射下でのシス, トランス異性体 の膜中濃度 $\bar{C}_{\mathrm{S} \text {, cis,tot }}^{\text {u.v }}, \bar{C}_{\mathrm{S} \text {,trans,tot }}^{\mathrm{u} . \mathrm{t}}$ を用いて, 式(19) から 光誘起膜電位変化を計算することができる，例えば，紫 外光照射下での $0.1 \mathrm{M}$ の $\mathrm{RbCl}$ 溶液に接している, イ オノフォア 1 を $1.0 \mathrm{mM}$ 含む液膜のトランス異性体濃 度は $0.58 \mathrm{mM}$, シス異性体濃度は $0.42 \mathrm{mM}$ であり, 溶 媒抽出より見積もった異性体間の $\mathrm{Rb}^{+}$イオンに対する 錯形成安定度定数の比 $\left(\beta_{\mathrm{IS} \text { cis }} / \beta_{\mathrm{IS}_{\mathrm{n}}, \text {,rans }}\right)$ は 1.93 であ る. すなわち, 膜界面での $\mathrm{Rb}^{+}$イオン錯体濃度 $\bar{C}_{\mathrm{IS}(\overline{0})}$ が 39\% 增加することに対応する．このデー夕を用いて 式(19）から計算した膜電位変化は $+8.2 \mathrm{mV}$ であり, 実際に観測された光誘起膜電位変化の值 $(+7.5 \mathrm{mV})$ に近い. Table 4 に式(19) を用いて計算した膜電位変 化の值をまとめて示す．いずれの場合にも，計算で求め た膜電位変化の值は, 実際に観測された光誘起膜電位変 化の值にかなり近いことが分かる.

それでは，液膜 ISEにおいてイオノフォア濃度が低 い場合しばしば観測されるネルンスト理論勾配からのず れは，どのように考えられるのであろうか．上述の界面 モデル II は，すべてのイオン種がボルツマン分布をし ているという仮定の下では，その界面電位の目的イオン 濃度依存性はネルンスト理論式による結果と等価であ り, 従って, 計算電位勾配のイオノフォア濃度依存性は 見られない（Fig. 10)。しかし実際には，膜中イオノフ オア濃度が低い場合, サブーネルンスト応答勾配が観測 される (Fig. 8c, d). 一方, サブーネルンスト応答が観 測される液膜にごく少量の脂溶性陰イオンである $\mathrm{KT} p \mathrm{ClPB}$ を添加すると, 電位応答勾配は大きくなりネ ルンスト勾配に近づく (Fig. 8e). 脂溶性陰イオンを添 加していない液膜中のイオン性サイトの由来が, 液膜の 支持材である PVCに結合したイオン性不純物（スルホ ン酸やカルボン酸残基として）であることが知られてい るので ${ }^{3132)}$ ，おそらくサブーネルンスト㐫答の理由の一 つは液膜中の陰イオン性サイトが膜中で移動できず，膜 界面でボルツマン則に従わない分布をしているためであ

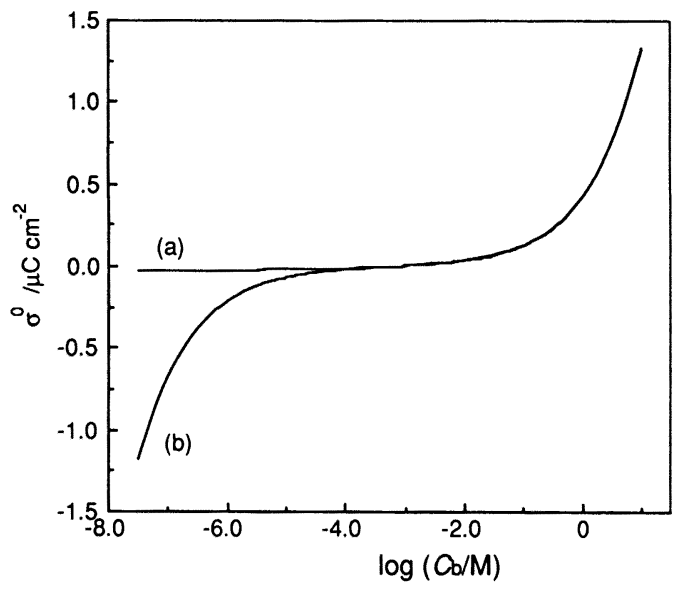

Fig. 11 Calculated surface charge density, $\sigma^{\circ}$, as a function of the primary cation concentration, $C_{\mathrm{b}}$. The curves (a) and (b) were obtained by using eqs 20 and 14, respectively. The following parameters were used: $\beta_{\mathrm{IS}}=1.0 \times 10^{10} \mathrm{M}^{-1}, \quad k_{1}=1.3 \times 10^{-8}$, $\varepsilon=78.3, \bar{\varepsilon}=4.0, \overline{C_{\mathrm{R}}}=0.05 \mathrm{mM}$.

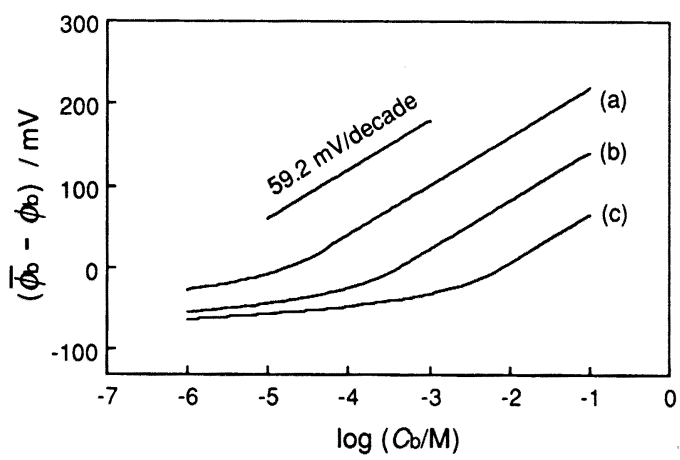

Fig. 12 Calculated potential differences, $\overline{\phi_{\mathrm{b}}}-\phi_{\mathrm{b}}$, as a function of the primary cation concentration with (a) $10 \mathrm{mM}$, (b) $1 \mathrm{mM}$ and (c) $0.1 \mathrm{mM}$ of the total ionophore concentration, respectively. The curves were obtained by using eq 20 . The following parameters were used: $\beta_{\mathrm{IS}}=1.0 \times 10^{10} \mathrm{M}^{-1}, k_{1}=$ $1.3 \times 10^{-8}, \varepsilon=78.3, \bar{\varepsilon}=4.0, \overline{C_{\mathrm{R}}}=0.05 \mathrm{mM}$.

ろう．そこで，膜中で固定化された陰イオン性サイトが 均一に分布している場合について考察を行った．膜中で の固定陰イオン濃度 $\bar{C}_{\mathrm{R}}$ がイオノフォア濃度に比べて十 分低い場合, 界面電荷密度は次式のように表現される。

$$
\sigma^{\circ}= \pm \sqrt{2 R T \varepsilon_{0} \bar{\varepsilon}} \sqrt{\bar{C}_{\mathrm{IS}(\overline{0})}-\bar{C}_{\mathrm{R}}\left(1+\ln \frac{\left.\bar{C}_{\mathrm{IS}(\overline{0})}\right)}{\bar{C}_{\mathrm{R}}}\right.}
$$




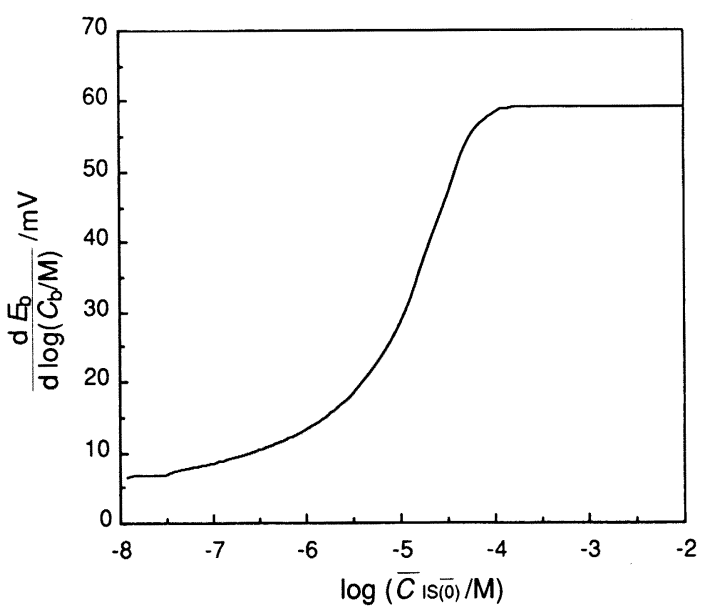

Fig. 13 Slope of the calculated potential differences, $\overline{\phi_{\mathrm{b}}}-\phi_{\mathrm{b}}$, as a function of the surface concentration of the ionophore-primary complex cation, $\bar{C}_{\text {Is }(\overline{0})}$. The curve was obtained by using eq 20 . The following parameters were used: $\varepsilon=78.3$, $\bar{\varepsilon}=4.0, \overline{C_{\mathrm{R}}}=0.05 \mathrm{mM}$.

膜中陰イオンが固定されている場合とボルツマン分布し ている場合について, 式(20) 及び（14）を用いて計算し た界面電荷密度と目的イオン濃度 $C_{\mathrm{b}}$ の関係を Fig. 11 に示す. 目的イオン濃度が高い場合, 式(20) 及び (14) を用いて計算した界面電荷密度の值はほぼ一致するが, 目的イオン濃度が低い場合, 膜中脂溶性陰イオンがボル ツマン分布に従うモデルでは界面電荷密度が負側に大き くなるのに対し, 固定陰イオンサイトモデルでは界面電 荷密度は非常に小さくほぼ一定の値となっていることが 分かる. Fig. 12 に式(20) に基づいて計算した界面電位 の水溶液中目的陽イオンの濃度依存性を示す. 高目的イ オン濃度領域では, 膜中イオン種がすべてボルツマン分 布則に従っていると仮定して算出した界面電位（Fig. 10）と一致しているが, 低目的陽イオン濃度領域ではそ の電位応答の挙動が大きく異なっている.すなわち, 目 的陽イオンの低濃度領域で電位応答勾配の減少, すなわ ちサブーネルンスト応答が見られ, 又その検出下限はイ オノフォア濃度が高いほざ，低くなっていることが分か る.この計算結果は, 実際に観測された光応答性イオノ フォアに基づく液膜における電位応答挙動の膜中イオノ フォア濃度依存性とよく一致している. Fig. 13 に, 式 （20）に基ついて計算した界面錯体濃度 $\bar{C}_{\mathrm{IS}(\overline{0})}$ と電位応 答勾配の関係を示した。計算により求めた応答勾配は, 界面錯体濃度の増加に伴ってネルンスト理論勾配まで増
大し，それ以上界面錯体濃度が増加しても増加せず一定 の値になっていることが分かる．そこでこの固定陰イオ ンサイトモデルを用いて, 光応答性イオノフォアに基づ く液膜の, 光照射によって誘起される電位応答勾配の変 化について解析した. イオノフォア 2 を $0.1 \mathrm{mM}$ 含む 液膜の場合, 可視光照射下での $\mathrm{Rb}^{+}$イオンに対する電 位応答勾配は, その $1 \times 10^{-3}$ から $1 \times 10^{-2} \mathrm{M}$ の濃度領 域で $38.5 \mathrm{mV} /$ decade である。この場合, Fig. 13 から 対忘する界面錯体濃度 $\bar{C}_{\mathrm{IS}(0)}$ は $1.74 \times 10^{-5} \mathrm{M}$ と読み取 れる. この液膜に紫外光を照射すると膜中シスーイオ, フォア 2 濃度の增加に伴って界面錯体濃度 $\bar{C}_{\mathrm{IS}(\overline{0})}$ が $55.4 \%$ 増加する.この界面錯体濃度の増加により, 電 位応答勾配が $44.8 \mathrm{mV} /$ decade に增大することが Fig. 13 から読み取られ, これは実際に観測された紫外光照 射下での電位応答勾配 $(44.1 \mathrm{mV} /$ decade $) に$ 近い。一 方, イオノフォア 2 を $1 \mathrm{mM}$ 含む液膜では, 可視光照 射下での $\mathrm{Rb}^{+}$イオンに対する電位応答勾配はネルンス 卜理論勾配に近く, $\mathrm{Rb}^{+}$イオン濃度が $1 \times 10^{-3}$ から $1 \times 10^{-2} \mathrm{M}$ の領域で $58.2 \mathrm{mV} /$ decade である.この場 合, 対応する界面錯体濃度 $\bar{C}_{\mathrm{IS}(\overline{0})}$ は約 $8 \times 10^{-5} \mathrm{M}$ と見 積もられる.ここで重要なことは，モデルより計算した 電位勾配は, Fig. 13 に示すように, 更に界面電荷密度 が増加したとしてもネルンスト応答勾配よりも大きくな らないことである.実際，イオノフォア 2 を $1 \mathrm{mM}$ 含 む液膜では，可視及び紫外光照射下での電位応答勾配は いずれもほぼ等しい。この計算電位勾配と観測された電 位勾配がよく一致するという結果より, 膜中陰イオン性 サイトが可動でない場合, 電位応答勾配及び検出下限を 決定する重要な要因は界面における目的イオンの取り込 み量であり，その大きさは膜中イオノフォア濃度によっ て支配されていると結論できる.

中性イオノフォアに基づく液膜 ISE のネルンスト応 答挙動からの逸脱の理由は, 実際にはしばしば観測され るのにもかかわらず，これまで十分に説明されてこなか った，光応答性イオノフォアを分子プローブとする本研 究のアプローチによって, サブーネルンスト応答が基本 的には膜界面の目的陽イオンの取り込み量が少ないこと に起因し, また膜中陰イオンの分布が膜電位応答挙動に 大きな影響を与えていることが検証された.

\section{4 おりに}

これまで, 液膜 ISE の界面電位は試料水溶液バルク 中の目的イオン活量と膜界面近傍の目的イオン活量の比 として記述されてきた 代 $(2)$ 参照\}。しかし, この界 面電位の取り扱いでは, 膜界面近傍というのは膜のどの 
ぐらいの深さの領域を意味しているのか, あるいは, 液 膜界面で錯形成していない目的イオンの濃度はどれぐら いなのかといった点で, 界面の描像は非常に不明りょう である，逆にこれが，これまで液膜界面における分子レ ベルでの電荷分離構造の重要性がほとんど議論されてこ なかった理由であるとも言える。これに対し，SHG 及 び分子プローブを用いるアプローチによって得られた， ISE 液膜界面のごく浅いデバイ長程度の領域で生成した 陽イオン錯体が膜電位を支配しているという本研究結果 は, 液膜 ISE 界面のイオン選択的電荷分離が界面電位 の本質であることを明らかにするとともに, その分子レ ベルでの理解に貢献するものである. 又, SHG 及び分 子プローブを用いた実験結果に基づいて本論文で提案し た液膜 ISE の界面モデルは, 液膜界面の陽イオン錯体 濃度 (界面電荷密度) と界面電位を関連付けるものであ る.しかしこのモデルでは, 液/液界面で水分子と膜溶 媒分子が入り混じった領域（いわゆる内部層）の問題,

界面を横切るイオンの輸送速度の問題, イオンの溶媒和 といった点を考慮しておらず,これらは今後の理論面,

実験面での研究課題である.

この研究は梅澤喜夫教授 (東京大学大学院理学系研究科) の下で行われたものであり, 先生の御指導に対して深く感 謝の意を表したい. 研究成果は小田嶋和徳助教授 (東京大 学薬学部), Philippe Buhlmann 博士 (東京大学大学院理学 系研究科助手), 片岡正光博士 (現小樽商科大学教授), 吉 谷川真司修士 (現北海道警察) 並びに北海道大学電子研究 所の川崎昌博教授との共同研究によるものである. 又, 九 州大学工学部の新海征治教授には, アゾビス(ベンゾ-15-ク ラウン-5）を提供していただいた。ここに関係者すべてに 謹んで感謝申し上げる.

\section{文献}

1) Z. Stefanac, W. Simon: Chimia, 20, 436 (1966).

2) L. A. R. Pioda, W. Simon: Chimia, 23, 72 (1969).

3) L. A. R. Pioda, V. Stankova, W. Simon: Anal. Lett., 2, 665 (1969).

4) U. Fiedler, J. Ruzicka: Anal. Chim. Acta, 67, 179 (1973).

5) H. F. Osswald, R. Asper, W. Dimai, W. Simon: Clin. Chem., 25, 39 (1979)

6) H. B. Jenny, C. Riess, D. Ammann, B. Magyar, R. Asper, W. Simon: Mikrochim. Acta, 1980, 309.

7) C. J. Pedersen: J. Am. Chem. Soc., 89, 2495 (1967).

8) D. J. Cram: Angew. Chem., Int. Ed. Engl., 27, 1009 (1988).
9) J. M. Lehn: Angew. Chem., Int. Ed. Engl., 27, 89 (1988)

10) Y. Umezawa, K. Umezawa: " $C R C$ Handbook of Ion-Selective Electrodes: Selectivity Coefficients", (1990), (CRC Press, Boca Raton).

11) M. Senda, T. Kakiuchi, T. Osakai: Electrochim. Acta, 36, 259 (1991).

12) W. E. Morf: "The Principles of Ion-Selective Electrodes and of Membrane Transport", (1981), (Elsevier, Amsterdam).

13) B. Doyle, G. L. Moody, J. D. R. Thomas: Talanta, 29, 609 (1982).

14) A. P. Thoma, A. Viviani-nauer, S. Arranitis, W. E. Morf, W. Simon: Anal. Chem., 49, 1567 (1977).

15) W. E. Morf, W. Simon: Helv. Chim. Acta, 69, 1120 (1986).

16) E. Pungor: Pure Appl. Chem., 64, 503 (1992).

17) K. Tohda, S. Yoshiyagawa, Y. Umezawa, S. Hashimoto, M. Kawasaki: Anal. Chem., 67, 570 (1995).

18) S. Yoshiyagawa, K. Tohda, Y. Umezawa, S. Hashimoto, M. Kawasaki: Anal. Sci., 9, 715 (1993)

19) K. Toth, E. Lindner, E. Pungor, E. Zippel, R. Kellner: Fresenius' Z. Anal. Chem., 331, 448 (1988).

20) K. Umezawa, X. M. Lin, S. Nishizawa, M. Sugawara, Y. Umezawa: Anal. Chim. Acta, 282, 247 (1993).

21) D. A. Higgins, R. M. Corn: J. Phys. Chem., 97, 489 (1993).

22) R. P. Buck: Anal. Chem., 48, 23R (1976).

23) J. Anzai, H. Sasaki, A. Ueno, T. Osa: J. Chem. Soc., Perkin Trans. II, 903 (1985).

24) J. Anzai, A. Ueno, T. Osa: J. Chem. Soc., Perkin Trans. II, 1987, 67

25) J. Anzai, Y. Hasebe, A. Ueno, T. Osa: J. Polym. Sci. Part A, Polym. Chem., 26, 1519 (1988).

26) S. Shinkai, T. Nakaji, T. Ogawa, K. Shigematsu, O. Manabe: J. Am. Chem. Soc., 103, 111 (1981).

27) A. Cadogan, Z. Gao, A. Lewenstam, A. Ivaska, D. Diamond: Anal. Chem., 64, 2496 (1992).

28) U. Oesch, W. Simon: Anal. Chem., 52, 692 (1980)

29) J. Anzai, S. Sakasegawa, T. Hoshi, T. Osa: Denki Kagaku, 7, 830 (1993).

30) Z. Samec: Chem. Rev., 88, 617 (1988).

31) P. Buhlmann, S. Yajima, K. Tohda, Y. Ume zawa: Electrochim. Acta, 40, 3021 (1995).

32) A. Hodinar and A. Jyo: Anal. Chem., 61, 1169 (1989). 


\begin{abstract}
要旨
レーザー光第二高調波発生（SHG）及び分子プローブを用いる新しい手法によって，イオン選択性 電極（ISE）液膜界面における電位心答機構を分子レベルで解积する研究を行った。イオノフォア含有 ISE 液膜/試料水溶液界面にレーザ一光を照射することにより SHG が発生し, その強度が試料水溶液 中の目的イオン濃度が増加するに従って増加することを見いだした。この結果は, 生成した陽イオン一 イオノフォア錯体が ISE 液膜界面で配向し SHG 活性種となっていることを示唆している. 又, ISE 液膜の目的イオンに対する SHG 強度変化と膜電位変化との相関より, 膜界面で配向した SHG 活性な 錯体陽イオン種が主に膜電位を支配していることを明らかにし，SHG 強度より見積もった界面電荷密 度に基づいて解析した．更に，膜電位と界面電荷密度の関係を定量的に調べるために，光照射によって 膜の状態を一切変えることなく, 膜中のイオノフォア濃度及びそのイオノフォアに配位するイオンとの 間の結合力（錯体安定度定数）を変化させることができる光応答性イオノフォアを分子プローブとして 利用し, 光で誘起された膜電位の絶対値及び電位応答勾配の変化量を, 液膜界面での錯形成平衡を考慮 した拡散電気二重層に基づく界面モデルを用いて定量的に説明した。
\end{abstract}

